\title{
Simple Atomic Absorption Spectroscopic and Spectrophotometric Methods for Determination of Pioglitazone Hydrochloride and Carvedilol in Pharmaceutical Dosage Forms
}

\author{
Afaf A. Abdelmonem, ${ }^{1}$ Gamal H. Ragab, ${ }^{1}$ Hisham Hashem, ${ }^{1,2}$ and Eman A. Bahgat ${ }^{1}$ \\ ${ }^{1}$ Faculty of Pharmacy, Pharmaceutical Analytical Chemistry Department, Zagazig University, Zagazig 44519, Egypt \\ ${ }^{2}$ Faculty of Pharmacy, Pharmaceutical Chemistry Department, Jazan University, Jazan 45142, Saudi Arabia \\ Correspondence should be addressed to Hisham Hashem; hisham413@yahoo.com
}

Received 31 January 2014; Revised 6 April 2014; Accepted 14 April 2014; Published 18 May 2014

Academic Editor: Shigehiko Takegami

Copyright (C) 2014 Afaf A. Abdelmonem et al. This is an open access article distributed under the Creative Commons Attribution License, which permits unrestricted use, distribution, and reproduction in any medium, provided the original work is properly cited.

\begin{abstract}
This study represents simple atomic absorption spectroscopic and spectrophotometric methods for determination of pioglitazone hydrochloride (PGZ-HCl) and carvedilol (CRV) based on formation of ion-pair associates between drugs and inorganic complex, bismuth(III) tetraiodide (Method A) and between drugs and organic acidic dyes, fast green and orange G (Method B). Method $\mathrm{A}$ is based on formation of ion-pair associate between drugs and bismuth(III) tetraiodide in acidic medium to form orange-red ion-pair associates, which can be quantitatively determined by two different procedures. The formed ion-pair associate is extracted by methylene chloride, dissolved in acetone, dried, and then decomposed by hydrochloric acid, and bismuth content is determined by direct atomic absorption spectrometric technique (Procedure 1) or extracted by methylene chloride, dissolved in acetone, and quantified spectrophotometrically at $490 \mathrm{~nm}$ (Procedure 2). Method B is based on formation of ion-pair associate between drugs and either fast green dye or orange $\mathrm{G}$ dye in acidic medium to form ion-pair associates. The formed ion-pair associate is extracted by methylene chloride and quantified spectrophotometrically at $630 \mathrm{~nm}$ (for fast green dye method) or $498 \mathrm{~nm}$ (for orange G dye method). Optimal experimental conditions have been studied. Both methods are applied for determination of the drugs in tablets without interference.
\end{abstract}

\section{Introduction}

PGZ-HCl, ( \pm )-5-\{p-[2-(5-ethyl-2-pyridyl) ethoxy] benzyl\}2,4-thiazolidine dione hydrochloride (Figure 1(a)), is a thiazolidine-dione oral antidiabetic similar to rosiglitazone. It is used in the management of type 2 diabetes mellitus. It is given orally as a monotherapy, particularly in patients who are overweight and for whom metformin is contraindicated or not tolerated [1].

Several spectrophotometric methods have been reported for estimation of PGZ-HCl including ion-pair complex formation with bromothymol blue, bromophenol blue and bromocresol purple [2], and chlorophenol red [3] as well as interaction with diazotized sulfanilic acid [4]. Derivative spectrophotometry [5] has been also applied. An atomic absorption spectrometric method for determination of PGZ$\mathrm{HCl}$ has been reported which is based on reaction of the drug with calcium disodium edentate and sodium chloride to give pink and violet colored metal complexes, respectively [6]. These complexes are readily extracted with chloroform and determined by atomic absorption spectrometer at 288.2 and $227.7 \mathrm{~nm}$, respectively [6]. Other methods include flow injection analysis [7] and voltametry [8]. Chromatographic methods [9-11] have been reported such as very rapid separation and quantitation of PGZ-HCl in presence of metformin$\mathrm{HCl}$ on monolithic column [9] as well as a stability indicating densitometric RP-TLC method [10].

CRV, (2RS)-1-(9H-carbazol-4-yloxy)-3-\{[2-(2-methoxyphenoxy) ethyl]amino\}-propan-2-ol (Figure 1(b)), is a betaadrenoceptor antagonist, an arteriolar vasodilator that is 


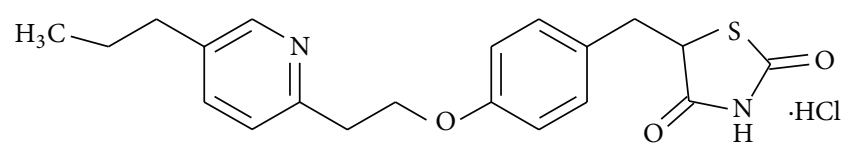

(a)

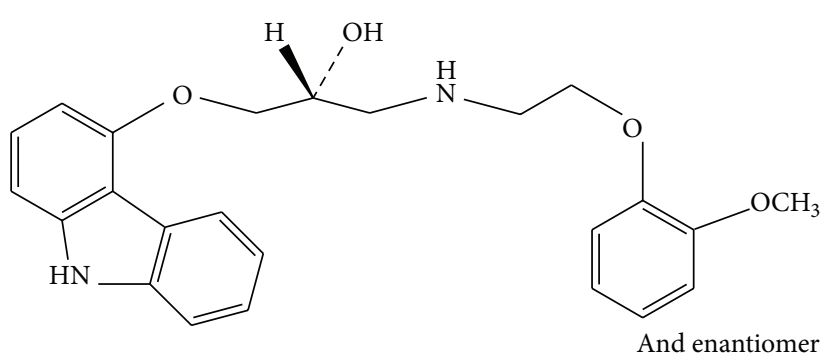

(b)

FIgUre 1: Chemical structures of (a) PGZ-HCl and (b) CRV.

indicated for the treatment of hypertension, angina pectoris, and heart failure [1].

CRV and its pharmaceutical formulations have been assayed in BP [14] which describes nonaqueous titration by dissolving the drug in anhydrous acetic acid and then titration with $0.1 \mathrm{M}$ perchloric acid, determining the endpoint potentiometrically. Several spectrophotometric methods have been reported for estimation of CRV including ion-pair complex formation with bromocresol green and bromothymol blue as well as charge-transfer reaction of the drug with the sigma-acceptor iodine [15]. Also UV spectrophotometric determination of CRV in pharmaceutical formulations was applied [16-18]. Other methods including determination of CRV by its quenching effect on the luminescence of terbium complex in dosage form [19], spectrofluorimetric determination via derivatization with 7-Chloro4-niritrobenzofurazon [20], and nonaqueous titration [21] have been described. Chromatographic methods have been reported such as validated HPLC determination of the fixed dose combination (CRV and hydrochlorothiazide) in their tablets [22], HPLC with fluorescence detection [23], and RPHPLC method for monitoring of the photochemical stability of CRV and its degradation products [24]. A Chiral HPLCseparation and determination of CRV from human urine was also noticed [25]. A stability-indicating HPLC-DAD determination of a mixture of carvedilol and hydrochlorothiazide [26] and also UPLC-MS/MS method for assay of carvedilol and its active metabolite in human plasma were introduced [27]. No atomic absorption spectrometric methods have been previously reported for CRV determination.

Bismuth(III)-iodide compounds have been used as reagents for determination of some nitrogenous drugs such as amineptine hydrochloride, piribedil, and trimebutine maleate [28]. It has been also used for spectrophotometric and atomic absorption spectroscopic determination of moxifloxacin hydrochloride [29] as well as levofloxacin, norfloxacin, and ciprofloxacin [30]. It has been also used for conductometric determination of lomefloxacine $\mathrm{HCl}$, pantoprazole sodium, and sumatriptan succinate [31]. On mixing aqueous solutions of bismuth(III) tetraiodide complex and the cited drugs in an acidic medium, a reddish orange precipitate instantaneously appeared that is attributed to the ion pair formed in the reaction (Scheme 1). The formed precipitates are then extracted and quantified spectrophotometrically at $490 \mathrm{~nm}$ or filtered, dried, and then decomposed by hydrochloric acid, and the bismuth content is determined by AAS at $223.1 \mathrm{~nm}$ [31].

Fast green FCF (Figure 2(a)) is an acidic dye used for spectrophotometric determination of some anthelmintics [32], mebeverine [33], and ceftiofur [34]. It has been also used for kinetic spectrophotometric determination of trace ruthenium [35] and in catalytic analysis of ultratrace ruthenium with oscillopolarographic detection [36].

Orange $\mathrm{G}$ (Figure 2(b)) is also an acidic dye used for spectrophotometric determination of citalopram hydrobromide, donepezil hydrochloride, rabeprazole sodium [37] from tablet formulation, omeprazole [38], tramadol hydrochloride [39], drotaverine hydrochloride [40], and some antihistaminic and skeletal muscle relaxant drugs [41]. It has been also used for spectrophotometric determination of trace ruthenium [42] and cationic and anionic surfactants in the presence of nonionic surfactants [43].

In this paper, new and simple atomic absorption spectroscopic and spectrophotometric methods are proposed for determination of some nitrogenous drugs, based on the formation of ion pair associated with Bi(III)-iodide complex, fast green or orange $\mathrm{G}$ dyes. The proposed methods have been applied to the assay of these drugs in tablets.

\section{Experiment}

2.1. Apparatus. All of the spectrophotometric measurements were carried out using a Shimadzu UV-1800 with matched $1 \mathrm{~cm}$ quartz cells (Japan). A Lutron digital pH-meter was used for $\mathrm{pH}$ adjustment (103 Taipei, Taiwan). Shimadzu atomic absorption spectrophotometric model AA-640-13 was used.

2.2. Materials. All solutions were prepared with analyticalgrade chemicals and water was always doubly distilled. The studied drugs were of pharmaceutical grade. Standard bismuth(III) solution, $3.3 \times 10^{-3} \mathrm{M}$, was prepared by dissolving $0.4824 \mathrm{~g}$ of bismuth subnitrate (Evans, united kingdom) in $5 \mathrm{~mL}$ of conc. $\mathrm{HNO}_{3}$ and adding distilled water and standardized complexometrically [43]. 0.5 M potassium iodide was prepared by dissolving $8.33 \mathrm{~g}$ of KI (Universal fine chemicals PVT-LTD, India) in $100 \mathrm{~mL}$ of water. Solutions of lower concentration were obtained by accurate dilution of these solutions with water. Acetic acid, hydrochloric acid, and sulphuric acid solutions of different molarities were prepared as in recommended methods [44]. Fast green FCF 
<smiles>CCc1ccc(CCOc2ccc(CC3SC(=O)NC3=O)cc2)nc1</smiles>

Pioglitazone-bismuth tetraiodide ion-pair associate<smiles>COc1ccccc1OCCNCC(O)COc1cccc2[nH]c3ccccc3c12</smiles>

Carvedilol $\downarrow \mathrm{H}^{+}$<smiles>Cc1ccccc1OCCNCC(O)COc1cccc2[nH]c3ccccc3c12</smiles>

Carvedilol-bismuth tetraiodide ion-pair associate

SCHEME 1: Proposed pathway for the reaction between the studied drugs and bismuth tetraiodate.<smiles>CCN(Cc1cccc([N+](=O)[O-])c1)c1ccc(C(=C2C=CC(=[N+](CC)Cc3cccc([S+](=O)([O-])[O-])c3)C=C2)c2ccc(O)cc2[O-])cc1</smiles>

(a)<smiles>O=[N+]([O-])c1cc([N+](=O)[O-])c2c(/N=N/c3ccccc3)c(O)ccc2c1</smiles>

(b)

FIGURE 2: Chemical structures of (a) fast green FCF and (b) orange-G. 
(Sigma Chem. Company, Milwaukee, WI, USA) was used as $0.01 \% \mathrm{w} / \mathrm{v}$ in double distilled water. Orange G (Sigma Chem. Company, Milwaukee WI, USA) was used as $0.2 \% \mathrm{w} / \mathrm{v}$ and $0.4 \% \mathrm{w} / \mathrm{v}$ in double distilled water.

2.3. Pharmaceutical Preparations. The following available pharmaceutical preparations were obtained from the Egyptian market and analyzed:

(i) Diabetin tablets containing $30 \mathrm{mg}$ PGZ-HCl per tablet (product of Unipharma, El-Obour city, Egypt);

(ii) Carvid tablets labeled to contain $25 \mathrm{mg}$ CRV per tablet (product of Multi-Apex Pharma, Badr city, Egypt).

\subsection{Preparation of Standard Drug Solutions}

For Method A. PGZ-HCl (Unipharma, El-Obour city, Egypt) stock solution, $0.25 \mathrm{mgmL}^{-1}$, was prepared by dissolving $12.5 \mathrm{mg}$ of PGZ in $5 \mathrm{~mL}$ of $0.1 \mathrm{M} \mathrm{HCI}$ and diluting to $50 \mathrm{~mL}$ with water (for both Procedure 1 and Procedure 2).

CRV (Amoun Pharmaceutical Co, El-Obour city, Egypt) stock solution was prepared by dissolving $50 \mathrm{mg}$ of the drug in methanol and diluting to $100 \mathrm{~mL}$ with methanol. A $12.5 \mathrm{~mL}$ aliquot of this solution was diluted to $25 \mathrm{~mL}$ with water to obtain drug with $0.25 \mathrm{mgmL}^{-1}$ concentration (for Procedure 1). Another CRV stock solution was prepared by dissolving $50 \mathrm{mg}$ of the drug in methanol and diluting to $50 \mathrm{~mL}$ with methanol. A $10 \mathrm{~mL}$ aliquot of this solution was diluted to $25 \mathrm{~mL}$ with water to obtain drug with $0.4 \mathrm{mgmL}^{-1}$ concentration (for Procedure 2).

For Method B. PGZ-HCl (Unipharma, El-Obour city, Egypt) working solution $50 \mu \mathrm{gmL}^{-1}$ and for molar ratio $1 \times 10^{-4} \mathrm{M}$ solution were prepared by dissolving in the least amount of $0.1 \mathrm{M} \mathrm{HCl}$ and then completing to volume with distilled water for fast green FCF method, while for orange G method, working solution $1000 \mu \mathrm{gmL}^{-1}$ and, for molar ratio, $2 \times$ $10^{-3} \mathrm{M}$ solution were prepared by dissolving in the least amount of $0.5 \mathrm{M} \mathrm{H}_{2} \mathrm{SO}_{4}$ and then completing to volume with distilled water.

CRV (Amoun Pharmaceutical Co, El-Obour city, Egypt) working solution $50 \mu \mathrm{gmL}^{-1}$ and for molar ratio $1 \times 10^{-4} \mathrm{M}$ solution were prepared by dissolving in the least amount of methanol and then completing to volume with distilled water for fast green FCF method, while for orange G method, working solution $500 \mu \mathrm{gmL}^{-1}$ and for molar ratio, $7 \times 10^{-4} \mathrm{M}$ solution were prepared by dissolving in the least amount of methanol and then completing to volume with distilled water.

\subsection{General Procedures}

\subsubsection{Construction of Calibration Curves}

\section{For Method A}

Procedure 1. Specified amounts of $3.3 \times 10^{-3} \mathrm{M}$ bismuth subnitrate and $0.5 \mathrm{M}$ KI solutions were placed in a $60 \mathrm{~mL}$ separating funnel. Different aliquots of $\mathrm{PGZ}-\mathrm{HCl}$ ranging from 0.1 to $1 \mathrm{~mL}$ of standard working solution and different aliquots of CRV ranging from 0.2 to $1.6 \mathrm{~mL}$ of standard working solution were added and $\mathrm{pH}$ is adjusted to 2.4 by adding an appropriate amount of $\mathrm{HNO}_{3}(2 \% \mathrm{v} / \mathrm{v})$. The solution was completed to $10 \mathrm{~mL}$ with water in case of PGZ$\mathrm{HCl}$, but no water was added in case of CRV, and then $5 \mathrm{~mL}$ of methylene chloride and $0.5 \mathrm{~mL}$ of acetone were added and shaken for 2 minutes. The organic layer was filtered through a Whatman no. 41 filter paper and dried in boiling water bath. The dried organic phase was dissolved in $0.5 \mathrm{~mL}$ Conc. $\mathrm{HCl}$ and the volume was completed to $5 \mathrm{~mL}$ with double distilled water. A blank omitting the drug was prepared under the same conditions. The bismuth absorbance was measured at the following conditions:

(i) analysis wavelength $223 \mathrm{~nm}$;

(ii) lamp current $5 \mathrm{~mA}$;

(iii) slit width $3.8 \AA$;

(iv) burner height $5 \mathrm{~mm}$;

(v) burner slot, flame $10 \mathrm{~cm}$, air- $\mathrm{C}_{2} \mathrm{H}_{2}$;

(vi) support gas flow $10 \mathrm{Lmin}^{-1}$;

(vii) fuel gas flow $2.6 \mathrm{Lmin}^{-1}$;

(viii) absorption sensitivity $0.6 \mathrm{ppm}$.

The concentration of the consumed bismuth was calculated from calibration graph of standard bismuth subnitrate solution.

Procedure 2. Specified amounts of $3.3 \times 10^{-3} \mathrm{M}$ bismuth subnitrate and $0.5 \mathrm{M}$ KI solutions were placed in a $60 \mathrm{~mL}$ separating funnel. Different aliquots of $\mathrm{PGZ}-\mathrm{HCl}$ ranging from 0.3 to $1.3 \mathrm{~mL}$ of standard working solution and different aliquots of CRV ranging from 0.2 to $0.9 \mathrm{~mL}$ of standard working solution were added and $\mathrm{pH}$ is adjusted to 2.4 by adding an appropriate amount of $\mathrm{HNO}_{3}(2 \% \mathrm{v} / \mathrm{v})$. The solution was completed to $10 \mathrm{~mL}$ with water in case of PGZ$\mathrm{HCl}$, but no water was added in case of CRV; then, $5 \mathrm{~mL}$ of methylene chloride and $0.5 \mathrm{~mL}$ of acetone were added for both drugs and shaken for 2 minutes. The organic layer was filtered through a Whatman no. 41 filter paper and measured at $490 \mathrm{~nm}$ against a reagent blank prepared and treated similarly.

\section{For Method B}

Fast Green FCF Method. Aliquots of standard solutions ranging from 0.1 to 0.7 and 0.1 to $0.6 \mathrm{~mL}$ of $\mathrm{PGZ}-\mathrm{HCl}$ and CRV, respectively, were transferred into a series of $60 \mathrm{~mL}$ separating funnels. To each separating funnel, $1 \mathrm{~mL}$ of fast green FCF dye $(0.01 \% \mathrm{w} / \mathrm{v})$ was added followed by specific volumes of acetic acid. PGZ-HCl produced intense color without using acetic acid. The formed ion pairs were extracted with $2 \times 5 \mathrm{~mL}$ of methylene chloride. The solutions were vigorously shaken for one minute and the separated organic layer dried over anhydrous sodium sulphate and transferred into $10 \mathrm{~mL}$ volumetric flasks. The volumes were completed to $10 \mathrm{~mL}$ with methylene chloride. The absorbance of the 
colored solutions was measured at $631 \mathrm{~nm}$ against reagent blank treated similarly.

Orange GMethod. Aliquots of standard solutions ranging from 0.1 to 0.7 and 0.2 to $0.9 \mathrm{~mL}$ of PGZ- $\mathrm{HCl}$ and CRV, respectively, were transferred into a series of $60 \mathrm{~mL}$ separating funnels. To PGZ-HCl and CRV, $0.5 \mathrm{~mL}$ of $0.4 \% \mathrm{w} / \mathrm{v}$ and $0.2 \% \mathrm{w} / \mathrm{v}$ orange $\mathrm{G}$ dye were added, respectively, followed by specific volumes of acetic acid. PGZ-HCl produced intense color without using acetic acid (Table 2). The formed ion pairs were extracted with $2 \times 5 \mathrm{~mL}$ of methylene chloride. The solutions were vigorously shaken for one minute and the separated organic layer was dried over anhydrous sodium sulphate and transferred into $10 \mathrm{~mL}$ volumetric flasks. The volumes were completed to $10 \mathrm{~mL}$ with methylene chloride. The absorbance of the colored solutions was measured at $498 \mathrm{~nm}$ against reagent blank treated similarly.

\subsubsection{Procedure for Dosage Forms}

\section{(1) Analysis of Diabetin Tablets (PGZ-HCl)}

For Method A. An accurately weighed amount of the powdered tablets equivalent to $25 \mathrm{mg}$ of the drug was transferred to a beaker and extracted with $5 \mathrm{~mL}$ of $0.1 \mathrm{M} \mathrm{HCl}$ for $10 \mathrm{~min}$ and diluted with water. The mixture was filtered through a filter paper and washed with water. The filtrate and washing were collected in a $50 \mathrm{~mL}$ volumetric flask and diluted to volume with water and then subjected to analysis by the recommended procedure.

\section{For Method B}

Fast Green FCF Method. Weigh and finely powder 10 tablets. Extract an accurately weighed portion of the powder equivalent to about $10 \mathrm{mg}$ of the drug with $10 \mathrm{~mL}$ of $0.1 \mathrm{M} \mathrm{HCl}$ by occasional shaking for 15 minutes. Filter the mixture into $100 \mathrm{~mL}$ calibrated flask, then wash the residue several times with the same solvent and dilute to $100 \mathrm{~mL}$ with the same solvent. Take $5 \mathrm{~mL}$ of this stock and dilute to $10 \mathrm{~mL}$ with distilled water.

Orange $G$ Method. Weigh and finely powder 10 tablets. Extract an accurately weighed portion of the powder equivalent to about $25 \mathrm{mg}$ of the drug with $10 \mathrm{~mL}$ of $0.5 \mathrm{M} \mathrm{H}_{2} \mathrm{SO}_{4}$ by occasional shaking for 15 minutes. Filter the mixture into $25 \mathrm{~mL}$ calibrated flask, wash the residue several times with the same solvent, and dilute to $25 \mathrm{~mL}$ with the same solvent.

\section{(2) Analysis of Carvid Tablets (CRV)}

For Method A. An accurately weighed amount of the powdered tablets equivalent to $50 \mathrm{mg}$ of the drug was transferred to a beaker, extracted with methanol, filtered through a filter paper, and washed with methanol. The filtrate and washing were collected in a $50 \mathrm{~mL}$ volumetric flask and diluting to volume with methanol. A $10 \mathrm{~mL}$ aliquot of this solution was diluted to $25 \mathrm{~mL}$ with water to obtain $0.4 \mathrm{mgmL}^{-1}$ of CRV and then subjected to analysis by the recommended procedure.

\section{For Method B}

Fast Green FCF Method. Weigh and finely powder 10 tablets. Extract an accurately weighed portion of the powder equivalent to about $25 \mathrm{mg}$ of the drug with $10 \mathrm{~mL}$ of methanol by occasional shaking for 15 minutes. Filter the mixture into $100 \mathrm{~mL}$ calibrated flask, wash the residue several times with the same solvent, and dilute to $100 \mathrm{~mL}$ with the same solvent. Take $10 \mathrm{~mL}$ of this stock and dilute to $50 \mathrm{~mL}$ with distilled water.

Orange G Method. Weigh and finely powder 10 tablets. Extract an accurately weighed portion of the powder equivalent to about $50 \mathrm{mg}$ of the drug with $10 \mathrm{~mL}$ of methanol by occasional shaking for 15 minutes. Filter the mixture into $50 \mathrm{~mL}$ calibrated flask, wash the residue several times with the same solvent, and dilute to $50 \mathrm{~mL}$ with the same solvent. Take $5 \mathrm{~mL}$ of this stock and dilute to $10 \mathrm{~mL}$ with distilled water.

\section{Results and Discussion}

3.1. For Method A. Bismuth(III)-iodide compounds have been used as reagents for the determination of some nitrogenous drugs. The formation of the ion pair between the secondary or tertiary amine group of the drug and $\mathrm{Bi}$ (III)iodide binary complex occurs via the protonated nitrogen atom of the drug. On mixing aqueous solutions of $\mathrm{Bi}$ (III)iodide complex and the cited drugs in an acidic medium, a reddish orange precipitate appears that is attributed to the ion pairs formed in the reaction. The extraction of these ion pairs with different solvents was studied. Only low-polarity solvents, such as chloroform, methylene chloride, and ethylene chloride, selectively extract the ion pairs. Methylene chloride was chosen as the extraction solvent because of its higher efficiency and considerable lower extraction ability for the reagent blank. Addition of a small amount of acetone proved to be useful. Ion pair in methylene chloride was measured over the wavelength range $400-560 \mathrm{~nm}$. The ion pair shows maximum absorbance at $490 \mathrm{~nm}$ (Figures 3 and 4), which can therefore be used as the wavelength for the analytical determination. The reagent blank at this wavelength has a low absorbance.

All measurements were performed against a reagent blank. Results are shown in Table 1. Different variables affecting the reaction were studied. It was not practical to aspirate the organic solvent of ion pair in the atomic absorption spectrometer because the high chlorine-carbon ratio would lead to the formation of a large quantity of $\mathrm{HCl}$ in the frame which would damage the instrument [41]. To avoid this damage, ion pair was extracted with organic solvent and dried and then the residue was dissolved in conc. $\mathrm{HCl}$. Different solvents were tried to dissolve the residue such as conc. ammonium hydroxide and conc. $\mathrm{HCl}$, and it was found that conc. $\mathrm{HCl}$ is the suitable solvent for dissolving the ion pair as it gives maximum solubility and best sensitivity.

3.1.1. Effect of $p H$. With increasing $\mathrm{pH}$ greater than 3 , there is a decrease in extraction yield, probably because of precipitation of bismuth as hydroxo-species. The absorbance at 
TABLE 1: Characteristic parameters for the reaction of PGZ-HCl and CRV with bismuth tetraiodide via Method A*.

\begin{tabular}{|c|c|c|c|c|}
\hline \multirow{2}{*}{ Parameters } & \multicolumn{2}{|c|}{ PGZ-HCl } & \multicolumn{2}{|c|}{ CRV } \\
\hline & Procedure 1 & Procedure 2 & Procedure 1 & Procedure 2 \\
\hline$\lambda_{\max }(\mathrm{nm})$ & 223 & 490 & 223 & 490 \\
\hline Beer's law limits $\left(\mu \mathrm{gmL}^{-1}\right)$ & $5-50$ & $15-65$ & $10-80$ & $16-72$ \\
\hline Vol. and conc. of bismuth subnitrate of $3.3 \times 10^{-3} \mathrm{M}$ & $0.3 \mathrm{~mL}$ & $0.3 \mathrm{~mL}$ & $0.4 \mathrm{~mL}$ & $0.4 \mathrm{~mL}$ \\
\hline Vol. and conc. of potassium iodide of $0.5 \mathrm{M}$ & $0.5 \mathrm{~mL}$ & $0.5 \mathrm{~mL}$ & $0.7 \mathrm{~mL}$ & $0.7 \mathrm{~mL}$ \\
\hline Extracting solvent & Methylene chloride & Methylene chloride & Methylene chloride & Methylene chloride \\
\hline \multicolumn{5}{|l|}{ Regression equation ${ }^{* *}$} \\
\hline Slope $(b)$ & 2.7642 & 0.0143 & 3.7383 & 0.0136 \\
\hline Intercept $(a)$ & 102.52 & 0.0177 & 55.097 & -0.0932 \\
\hline Correlation coefficient $\left(r^{2}\right)$ & 0.9999 & 0.9999 & 0.9999 & 0.9999 \\
\hline Molar ratio & $1: 1$ & $1: 1$ & $1: 1$ & $1: 1$ \\
\hline
\end{tabular}

${ }^{*}$ Average of three experiments.

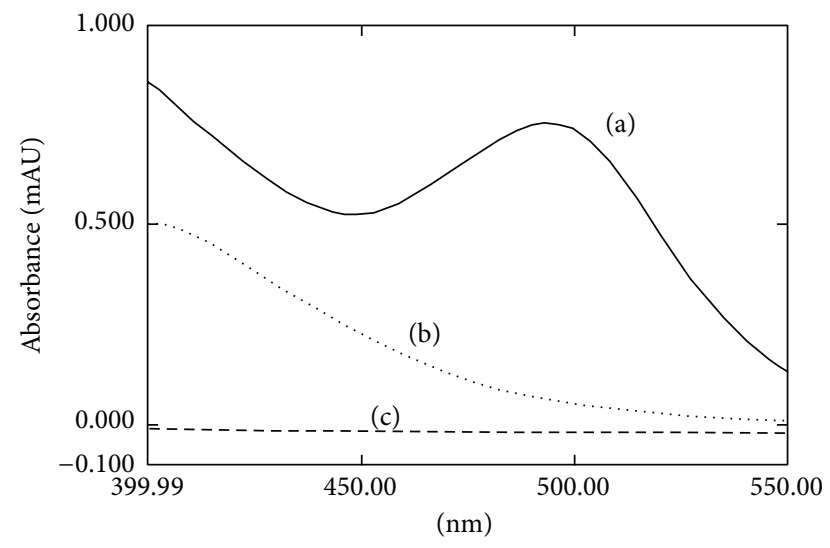

FIGURE 3: Absorption spectra of (a) the reaction of $50 \mu \mathrm{gmL}^{-1}$ PGZ$\mathrm{HCl}$ with $0.3 \mathrm{~mL}$ of $3.3 \times 10^{-3} \mathrm{M}$ bismuth subnitrate and $0.5 \mathrm{~mL}$ of $0.5 \mathrm{M}$ potassium iodide, (b) $0.3 \mathrm{~mL}$ of $3.3 \times 10^{-3} \mathrm{M}$ bismuth subnitrate and $0.5 \mathrm{~mL}$ of $0.5 \mathrm{M}$ potassium iodide, and (c) $50 \mu \mathrm{gmL}^{-1}$ $\mathrm{PGZ}-\mathrm{HCl}$ against methylene chloride.

$\lambda_{\max }$ remains constant in the $\mathrm{pH}$ range of $2.0-2.8$. As the shape of the absorption maximum does not vary with $\mathrm{pH}$, it is assumed that in this $\mathrm{pH}$ range only one type of ion pair is formed. The use of a suitable buffer solution was avoided because the presence of any foreign ion could interfere with the ion-pair formation; hence, $2 \%(\mathrm{v} / \mathrm{v})$ of $\mathrm{HNO}_{3}$ was used to adjust the $\mathrm{pH}$ of the solution.

3.1.2. Effect of Bismuth Subnitrate Volume. Different volumes of bismuth subnitrate were added to a fixed concentration of each drug in the presence of other constituents of the procedure. It was found that $0.4 \mathrm{~mL}$ of $3.3 \times 10^{-3} \mathrm{M}$ bismuth subnitrate solution for CRV and $0.3 \mathrm{~mL}$ for $\mathrm{PGZ}-\mathrm{HCl}$ were sufficient for the production of maximum and reproducible colour intensity (Figure 5).

3.1.3. Effect of Potassium Iodide Volume. Different volumes of potassium iodide were added to a fixed concentration of each

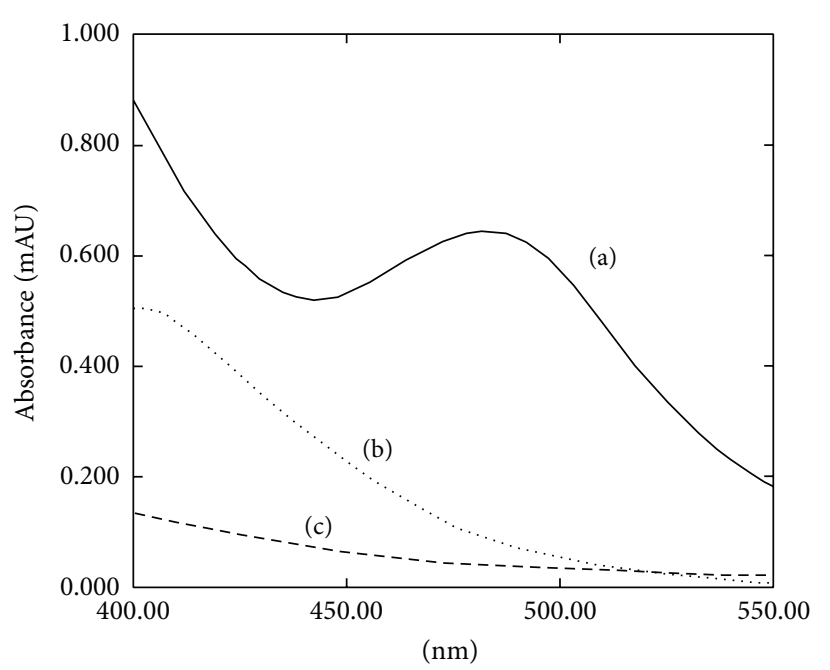

FIGURE 4: Absorption spectra of (a) the reaction of $56 \mu \mathrm{gmL}^{-1} \mathrm{CRV}$ with $0.4 \mathrm{~mL}$ of $3.3 \times 10^{-3} \mathrm{M}$ bismuth subnitrate and $0.7 \mathrm{~mL}$ of $0.5 \mathrm{M}$ potassium iodide, (b) $0.4 \mathrm{~mL}$ of $3.3 \times 10^{-3} \mathrm{M}$ bismuth subnitrate and $0.7 \mathrm{~mL}$ of $0.5 \mathrm{M}$ potassium iodide against methylene chloride, and (c) $56 \mu \mathrm{gmL}^{-1} \mathrm{CRV}$ against methylene chloride.

drug in the presence of other constituents of the procedure. It was found that $0.5 \mathrm{~mL}$ of $0.5 \mathrm{M}$ potassium iodide solution was suitable for PGZ-HCl, while $0.7 \mathrm{~mL}$ for $\mathrm{CRV}$ was sufficient for the production of maximum and reproducible color intensity (Figure 6).

3.1.4. Effect of Nitric Acid Volume. Different volumes of nitric acid were added to a fixed concentration of each drug in the presence of other constituents of the procedure. It was found that $0.7 \mathrm{~mL}$ of $2 \%(\mathrm{v} / \mathrm{v})$ of nitric acid solution was suitable for PGZ-HCl, while $0.3 \mathrm{~mL}$ for CRV was sufficient for the production of maximum and reproducible color intensity (Figure 7).

3.1.5. Effect of Extracting Solvent. Many organic solvents were tried to extract the binary complexes formed. Preliminary 


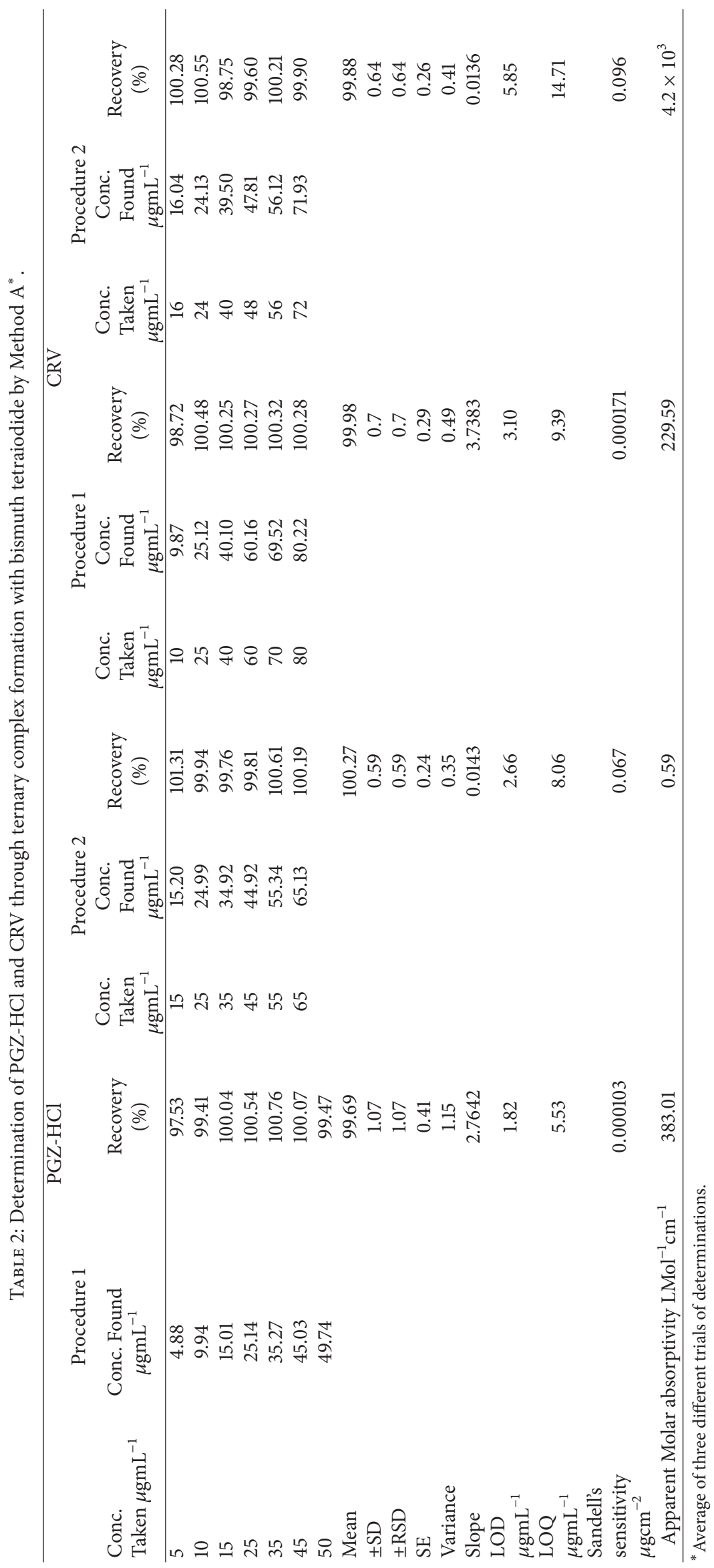




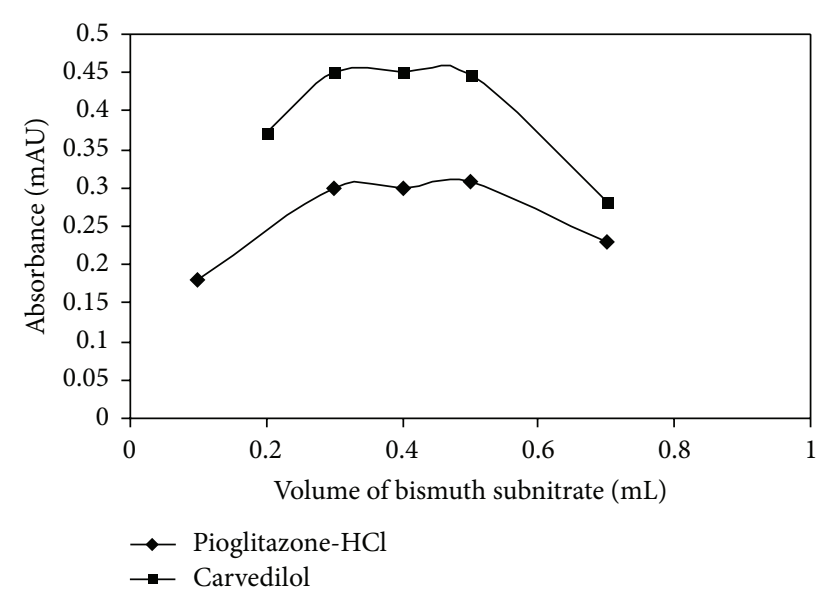

FIgURE 5: Effect of volume of $3.3 \times 10^{-3} \mathrm{M}$ bismuth subnitrate on the ion pair formed with (i) $20 \mu \mathrm{gmL}^{-1} \mathrm{PGZ}-\mathrm{HCl}$ and $0.5 \mathrm{~mL}$ $0.5 \mathrm{M}$ potassium iodide and (ii) $40 \mu \mathrm{gmL}^{-1} \mathrm{CRV}$ and $0.7 \mathrm{~mL} 0.5 \mathrm{M}$ potassium iodide.

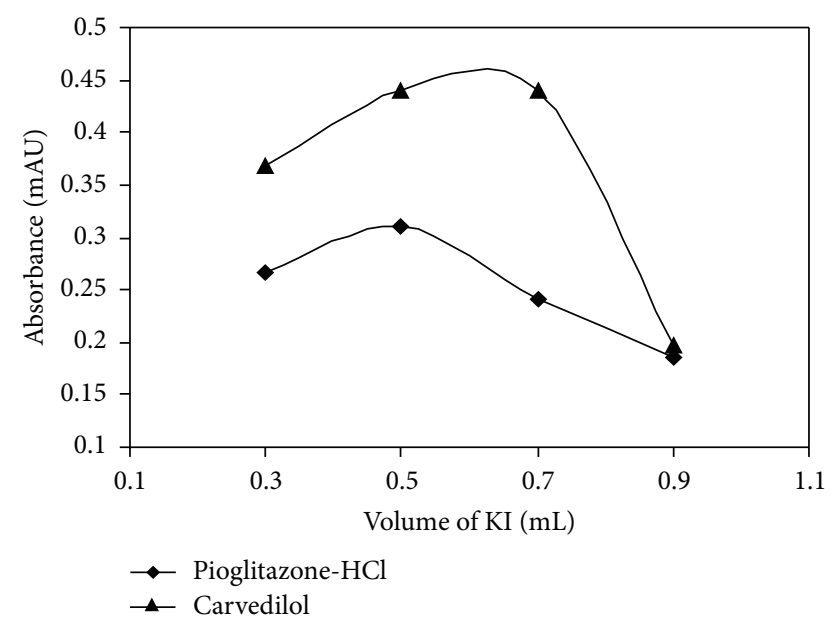

Figure 6: Effect of volume of 0.5 M Potassium iodide on the ion pair formed with (i) $20 \mu \mathrm{gmL}^{-1} \mathrm{PGZ}-\mathrm{HCl}$ and $0.3 \mathrm{~mL} 3.3 \times 10^{-3} \mathrm{M}$ bismuth subnitrate and (ii) $40 \mu \mathrm{gmL}^{-1} \mathrm{CRV}$ and $0.4 \mathrm{~mL} 3.3 \times 10^{-3} \mathrm{M}$ bismuth subnitrate.

experiments with number of organic solvents commonly used such as methylene chloride, ethyl acetate, ethylene chloride, benzene, and petroleum ether were constructed. It was found that methylene chloride was the appropriate solvent for the studied drugs.

3.1.6. Effect of Addition Order. The sequence of addition of the constituents of the complex was studied. The most suitable order was bismuth subnitrate, potassium iodide, drug, and then nitric acid to give most stability with higher sensitivity complex.

3.1.7. Effect of Reaction and Shaking Times. Maximum color intensity was attained immediately for CRV, while PGZ-HCl needed 5 minutes and complete extraction was attained by

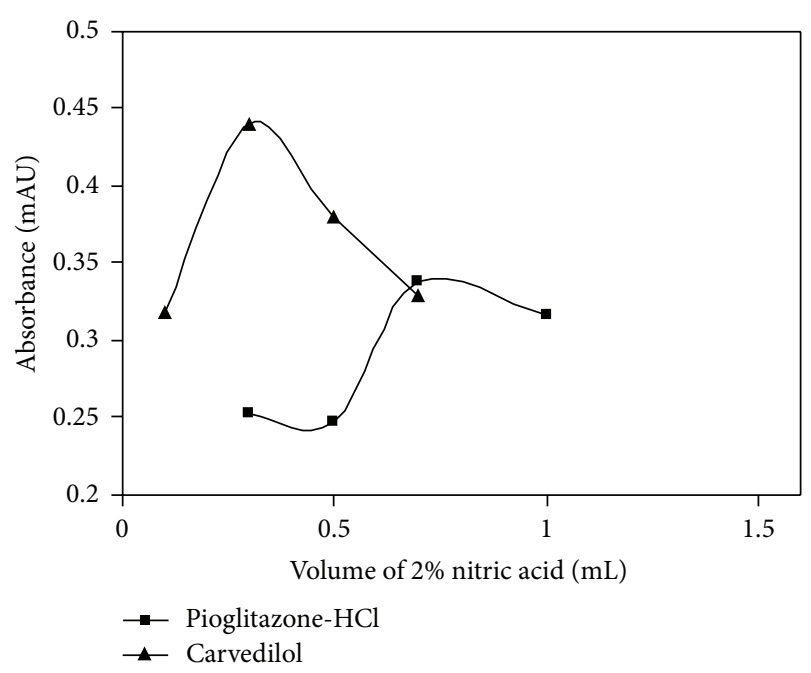

FIGURE 7: Effect of volume of $2 \%$ nitric acid on the ion pair formed with (i) $20 \mu \mathrm{gmL}^{-1} \mathrm{PGZ}-\mathrm{HCl}$ and (ii) $40 \mu \mathrm{gmL}^{-1} \mathrm{CRV}$.

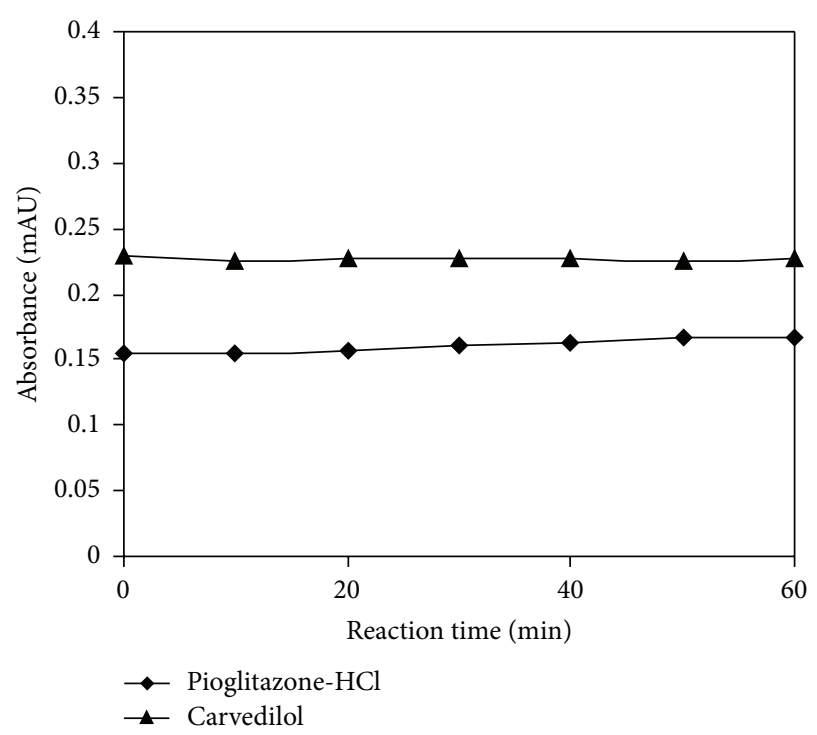

FIGURE 8: Stability of the ion pair formed between bismuth tetraiodide and both (i) $10 \mu \mathrm{gmL}^{-1} \mathrm{PGZ}-\mathrm{HCl}$ and (ii) $24 \mu \mathrm{gmL}^{-1} \mathrm{CRV}$.

shaking for 1 minute for PGZ-HCl and 2 minutes for CRV. The intensities of the color produced were found to be stable for more than 1 hour (Figure 8).

3.1.8. Composition of the Ion Pair. The composition of the ion pairs formed was studied by Job's method of nonequimolar solutions [45]. Bismuth subnitrate molecule contains five atoms of bismuth, so upon reaction with potassium iodide it gives five molecules of bismuth tetraiodide complex; after that the formed complex interacts with the studied drugs, which contain one site for the interaction, and gives the ion pair in the ratio $(5: 1)$, but this is difficult practically; nonequimolar solutions method is used for determination of the molar ratio of the formed ion pair. The obtained results showed that 


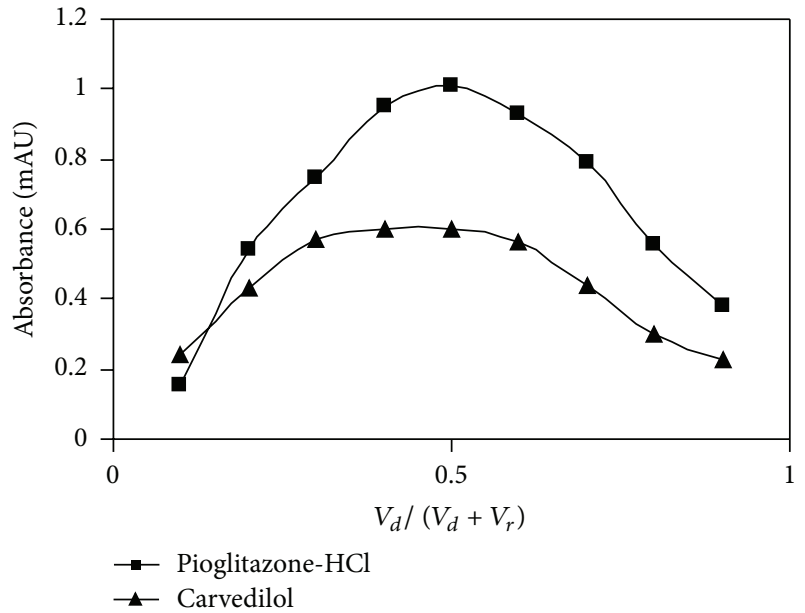

FIGURE 9: Continuous variation plot for PGZ-HCl $\left(1.3 \times 10^{-3} \mathrm{M}\right)$ and $\operatorname{CRV}\left(1.3 \times 10^{-3} \mathrm{M}\right)$ with bismuth subnitrate $\left(2.6 \times 10^{-4} \mathrm{M}\right)$.

the composition of the ion pairs was $(1: 1)$ for both drugs (Figure 9).

Method Validation. The method was validated according to the International Conference of Harmonization (ICH) [46].

\section{(1) Linearity and Concentration Ranges}

For Procedure 1. Graph of the absorbance against concentrations proved to be linear in the range from 5 to $50 \mu \mathrm{gmL}^{-1}$ for PGZ-HCl and from 10 to $80 \mu \mathrm{gmL}^{-1}$ for CRV and determination coefficients $\left(R^{2}\right)$ were 0.9999 for both drugs.

For Procedure 2. Graph of the absorbance against concentrations proved to be linear in the range from 15 to $65 \mu \mathrm{gmL}^{-1}$ for PGZ-HCl and from 16 to $72 \mu \mathrm{gmL}^{-1}$ for CRV and determination coefficients $\left(R^{2}\right)$ were 0.9999 for both drugs.

\section{(2) Limits of Detection and Limits of Quantitation}

For Procedure 1. Limit of detection (LOD) was found to be 1.82 and $3.10 \mu \mathrm{gmL}^{-1}$ for PGZ-HCl and CRV, respectively. Limit of quantitation (LOQ) was found to be $5.53 \mu \mathrm{gmL}^{-1}$ and $9.93 \mu \mathrm{gmL}^{-1}$ for PGZ-HCl and CRV, respectively.

For Procedure 2. Limit of detection (LOD) was found to be 2.66 and $5.58 \mu \mathrm{gmL}^{-1}$ for PGZ-HCl and CRV, respectively. Limit of quantitation (LOQ) was found to be $8.06 \mu \mathrm{gmL}^{-1}$ and $14.71 \mu \mathrm{gmL}^{-1}$ for PGZ-HCl and CRV, respectively. Results are given in Table 2 .

(3) Specificity of the Method. Results of the analysis were compared statistically to a reported method for PGZ-HCl and CRV applying the Student's $t$-test and the variance ratio test $(F$-test). The results gave lower values than the theoretical ones indicating no significant difference between

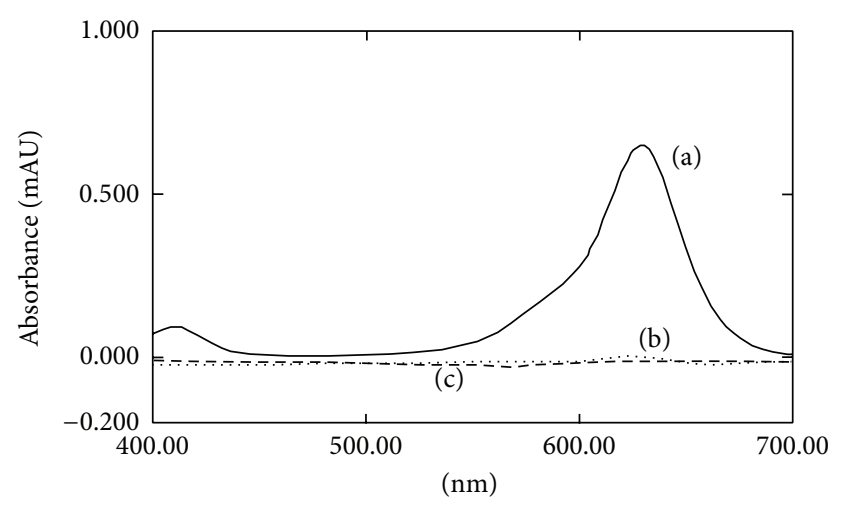

FIGURE 10: Absorption spectra of (a) the reaction of $3 \mu \mathrm{gmL}^{-1}$ PGZ$\mathrm{HCl}$ with $1 \mathrm{~mL}$ fast green $\mathrm{FCF}(0.01 \%$, w/v), (b) $1 \mathrm{~mL}$ fast green $\mathrm{FCF}(0.01 \%, \mathrm{w} / \mathrm{v})$ against methylene chloride, and (c) $3 \mu \mathrm{gmL}^{-1}$ PGZ-HCl against methylene chloride.

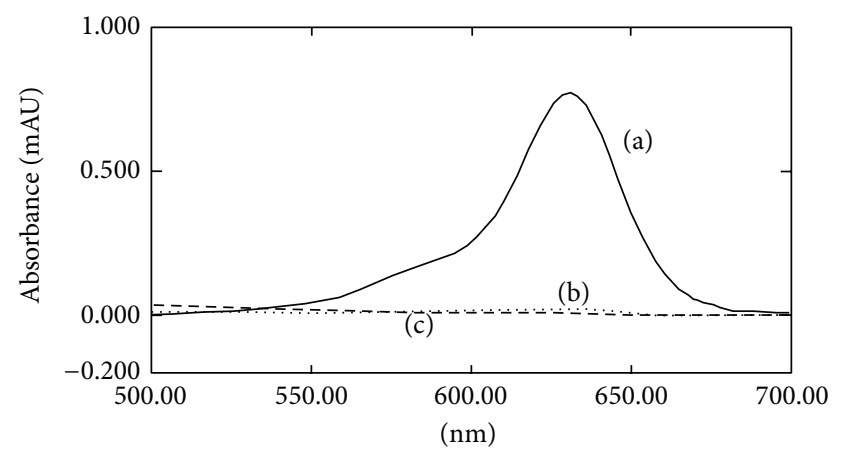

FIgURE 11: Absorption spectra of (a) the reaction of $2.5 \mu \mathrm{gmL}^{-1}$ CRV with $1 \mathrm{~mL}$ fast green FCF $(0.01 \%$, w/v), (b) $1 \mathrm{~mL}$ fast green $\mathrm{FCF}\left(0.01 \%\right.$, w/v) against methylene chloride, and (c) $2.5 \mu \mathrm{gmL}^{-1}$ CRV against methylene chloride.

the performance of the proposed method and the reported methods (Table 3).

(4) Repeatability and Precision of the Method. Table 4 shows that there are high intra- and interday precision. Intraday precision was assessed by injection of the standard solution of the drug at three concentration levels six times during a day. The same was done for interday precision test except that the experiment was done and the drugs were analyzed every day for six days.

\subsection{Reaction with Organic Dyes (Method B)}

3.2.1. Fast Green FCF Method. Absorption spectra of the reagents with $\mathrm{PGZ}-\mathrm{HCl}$ and $\mathrm{CRV}$ were studied over range of $200-800 \mathrm{~nm}$.

Fast green FCF reacts with PGZ-HCl and CRV to yield a blue colored complex exhibiting maximum absorption at $631 \mathrm{~nm}$ (Figures 10 and 11), and the ion pair formed can 
TABLE 3: Statistical analysis of results obtained by Method A applied on Diabetin tablets and Carvid tablets compared with reference methods.

\begin{tabular}{|c|c|c|c|c|c|c|c|c|}
\hline \multirow[b]{2}{*}{ Parameters } & \multicolumn{2}{|c|}{ Procedure 1} & \multicolumn{2}{|c|}{ Procedure 2} & \multicolumn{2}{|c|}{ Procedure 1} & \multicolumn{2}{|c|}{ Procedure 2} \\
\hline & $\begin{array}{c}\text { Diabetin } \\
\text { tablets }\end{array}$ & $\begin{array}{c}\text { Reference } \\
\text { method [12] }\end{array}$ & $\begin{array}{c}\text { Diabetin } \\
\text { tablets }\end{array}$ & $\begin{array}{l}\text { Reference } \\
\text { method [12] }\end{array}$ & $\begin{array}{l}\text { Carvid } \\
\text { tablets }\end{array}$ & $\begin{array}{c}\text { Reference } \\
\text { method [13] }\end{array}$ & $\begin{array}{l}\text { Carvid } \\
\text { tablets }\end{array}$ & $\begin{array}{r}\text { Reference } \\
\text { method [13 }\end{array}$ \\
\hline$N$ & 4 & 8 & 5 & 8 & 5 & 8 & 5 & 8 \\
\hline $\begin{array}{l}\text { Mean } \\
\text { recovery }\end{array}$ & 100.77 & 100.23 & 100.74 & 100.23 & 100.88 & 100.02 & 99.35 & 100.02 \\
\hline Variance & 1.12 & 0.85 & 0.66 & 0.85 & 0.80 & 0.64 & 0.29 & 0.64 \\
\hline \pm S.D. & 1.06 & 0.92 & 0.81 & 0.92 & 0.89 & 0.80 & 0.53 & 0.80 \\
\hline \pm R.S.D. & 1.11 & 0.92 & 0.80 & 0.92 & 0.88 & 0.80 & 0.53 & 0.80 \\
\hline \pm S.E. & 0.53 & 0.33 & 0.36 & 0.33 & 0.40 & 0.28 & 0.24 & 0.28 \\
\hline $\begin{array}{l}\text { Student's } \\
t \text {-test }\end{array}$ & $\begin{array}{c}0.914 \\
(2.23)^{\mathrm{a}}\end{array}$ & & $\begin{array}{c}1.01 \\
(2.20)^{\mathrm{a}}\end{array}$ & & $\begin{array}{c}1.81 \\
(2.20)^{\mathrm{a}}\end{array}$ & & $\begin{array}{c}1.64 \\
(2.20)^{\mathrm{a}}\end{array}$ & \\
\hline$F$-test & $\begin{array}{c}1.32 \\
(4.35)^{\mathrm{b}}\end{array}$ & & $\begin{array}{c}1.29 \\
(4.12)^{\mathrm{b}}\end{array}$ & & $\begin{array}{c}1.25 \\
(4.12)^{\mathrm{b}}\end{array}$ & & $\begin{array}{c}2.21 \\
(4.12)^{\mathrm{b}}\end{array}$ & \\
\hline
\end{tabular}

$\mathrm{a}$ and $\mathrm{b}$ are the theoretical student $t$-values and $F$-ratios at $P=0.05$.

TABLE 4: Evaluation of the interday and intraday precision and accuracy for PGZ-HCl and CRV through Method A.

\begin{tabular}{|c|c|c|c|c|c|c|c|}
\hline \multirow[b]{2}{*}{ Drug } & \multirow{2}{*}{$\begin{array}{l}\text { Taken } \\
\text { conc } \\
\left(\mu \mathrm{gmL}^{-1}\right)\end{array}$} & \multicolumn{3}{|c|}{ Interday } & \multicolumn{3}{|c|}{ Intraday } \\
\hline & & $\begin{array}{c}\text { Recovery } \\
(\%)^{\mathrm{a}}\end{array}$ & $\begin{array}{l}\text { Precision } \\
(\mathrm{RSD} \%)^{\mathrm{a}}\end{array}$ & $\begin{array}{c}\text { Accuracy } \\
(\text { Er\%) }\end{array}$ & $\begin{array}{c}\text { Recovery } \\
(\%)^{\mathrm{a}}\end{array}$ & $\begin{array}{l}\text { Precision } \\
(\mathrm{RSD} \%)^{\mathrm{a}}\end{array}$ & $\begin{array}{c}\text { Accuracy } \\
(\text { Er\%) }\end{array}$ \\
\hline \multirow{3}{*}{$\begin{array}{l}\text { PGZ- } \\
\mathrm{HCl}\end{array}$} & 10 & 99.65 & 0.76 & -0.35 & 100.93 & 1.19 & 0.93 \\
\hline & 15 & 100.84 & 0.92 & 0.84 & 100.57 & 1.03 & 0.57 \\
\hline & 40 & 100.19 & 0.53 & 0.19 & 100.22 & 0.89 & 0.22 \\
\hline \multirow{3}{*}{ CRV } & 15 & 99.57 & 1.16 & -0.43 & 99.17 & 0.78 & -0.83 \\
\hline & 24 & 99.98 & 0.78 & -0.02 & 99.81 & 1.21 & -0.19 \\
\hline & 50 & 99.06 & 0.95 & -0.94 & 100.85 & 1.45 & 0.85 \\
\hline
\end{tabular}

RSD\%: percentage relative standard deviation.

Er\%: percentage relative error.

${ }^{\mathrm{a}}$ Mean of five trials of determination.

be extracted with methylene chloride. Different variables affecting the reaction were studied.

(1) Effect of $p H$ on the Ion-Pair Formations. In order to establish the optimum $\mathrm{pH}$ value for each ion pair formed, various acids, for example, acetic, hydrochloric, and sulphuric acids of different molarities, were studied. The highest absorbance values were obtained using $0.1 \mathrm{M}$ hydrochloric acid and $0.01 \mathrm{M}$ acetic acid for PGZ-HCl and CRV, respectively. The optimum volume used for CRV was $0.4 \mathrm{~mL}$ of $0.01 \mathrm{M}$ acetic acid to give the highest absorbance values, while $0.1 \mathrm{M}$ hydrochloric acid was used as solvent for PGZ-HCl and for acidification of the medium (Figure 12).

(2) Effect of Reagent Conc. and Volume as well as Additions Order. The effect of reagent concentration was also studied. Highest constant absorbance was obtained on using $1 \mathrm{~mL}$ of fast green FCF $(0.01 \% \mathrm{w} / \mathrm{v})$ for both drugs PGZ-HCl and CRV (Figure 13). Moreover, the sequence of addition of the constituents of the complex was also studied. Addition of the drug followed by the dye and then the acid was recommended to obtain stable, high color intensity.

(3) Choice of Organic Solvent. A solvent is needed to extract the formed ion-pair to increase the selectivity of the assay.

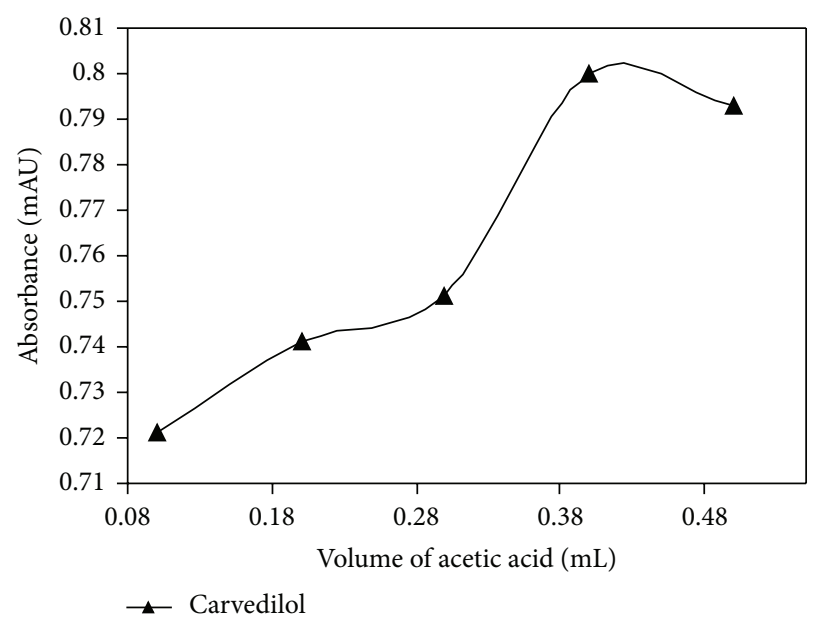

FIGURE 12: Effect of HAc volume on the ion-pair complex formation between $0.01 \% \mathrm{w} / \mathrm{v}$ fast green FCF and $2.5 \mu \mathrm{gmL}^{-1} \mathrm{CRV}$.

Preliminary experiment with a number of organic solvents commonly used (benzene, ethylacetate, methylene chloride, and ethylene chloride) for the ion-pair extraction was studied. Methylene chloride was the appropriate solvent because 
TABLE 5: Analytical parameters for the determination of PGZ-HCl and CRV via Method B.

\begin{tabular}{|c|c|c|c|c|}
\hline \multirow[t]{2}{*}{ Parameters } & \multicolumn{2}{|c|}{ PGZ-HCl } & \multicolumn{2}{|c|}{ CRV } \\
\hline & Fast green FCF & Orange G & Fast green FCF & Orange $\mathrm{G}$ \\
\hline Conc. of reagent, w/v & $0.01 \%$ & $0.4 \%$ & $0.01 \%$ & $0.2 \%$ \\
\hline Vol. of reagent, mL & 1 & 0.5 & 1 & 0.5 \\
\hline$\lambda_{\max }, \mathrm{nm}$ & 631 & 498 & 631 & 498 \\
\hline Beer's law limits $\mu \mathrm{gmL}^{-1}$ & $0.5-4$ & $10-70$ & $0.5-3$ & $5-45$ \\
\hline \multicolumn{5}{|l|}{ Regression equation* } \\
\hline Intercept & 0.1116 & -0.0413 & -0.0055 & 0.0168 \\
\hline Slope & 0.1945 & 0.0143 & 0.3201 & 0.0206 \\
\hline Correlation Coefficient & 0.9999 & 0.9999 & 0.9999 & 0.9999 \\
\hline Molar Ratio & $2: 3$ & $1: 1$ & $1: 1$ & $1: 1$ \\
\hline
\end{tabular}

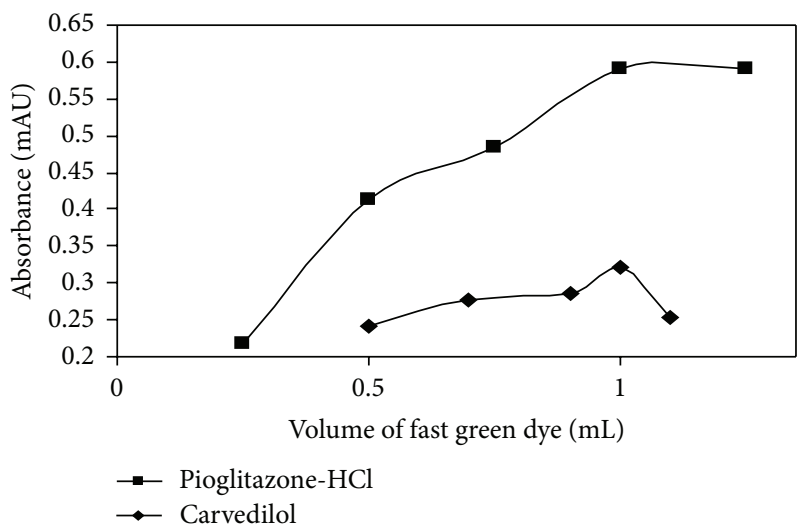

FIGURE 13: Effect of volume of $0.01 \% \mathrm{w} / \mathrm{v}$ fast green FCF dye on the ion-pair complex formation with $2.5 \mu \mathrm{gmL} \mathrm{m}^{-1} \mathrm{PGZ}-\mathrm{HCl}$ and $1 \mu \mathrm{gmL}^{-1} \mathrm{CRV}$, respectively.

of its higher sensitivity and lower extraction ability of the reagents.

(4) Effect of Reaction Time and Number of Extraction Times. Reaction time required for complete color development of ion-pair complexes formed between the studied drugs and fast green FCF was studied. Maximum color intensity was attained immediately for both drugs to reach its maximum intensity. Complete extraction was attained by double extraction with $(2 \times 5 \mathrm{~mL})$ methylene chloride and then complete to $10 \mathrm{~mL}$ with the same solvent. The intensities of the color produced were found to be stable for about $1 \mathrm{hr}$ for both drugs (Figure 14).

(5) Composition of the Ion-Pair Complexes. The composition of the ion pair was studied by Job's method of continuous variation [44]. The obtained results showed that the composition of ion pair complexes was $(1: 1)$ (drug : reagent) for PGZ-HCl and (2:3) (drug: reagent) for CRV (Figure 15).

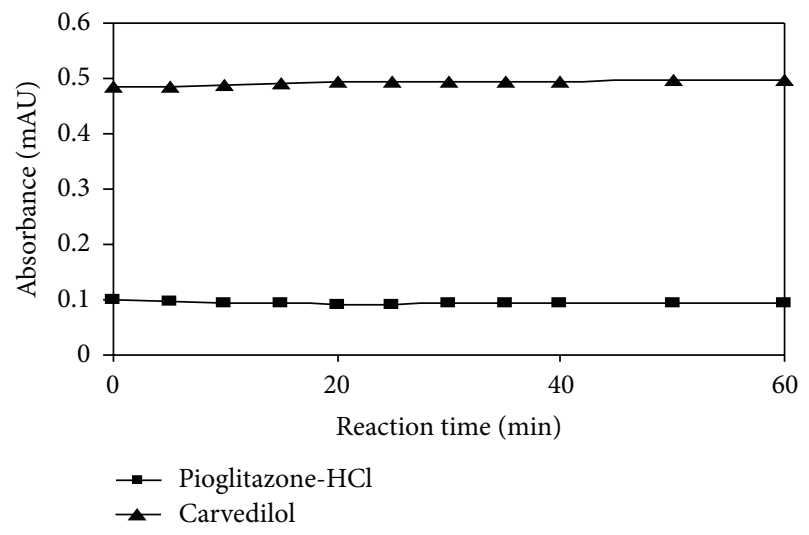

FIGURE 14: Stability of the ion pair formed between fast green FCF and both (i) $0.5 \mu \mathrm{gmL}^{-1} \mathrm{PGZ}-\mathrm{HCl}$ and (ii) $1.5 \mu \mathrm{gmL}^{-1} \mathrm{CRV}$.

3.2.2. Orange G Method. Absorption spectra of the reagents with PGZ-HCl and CRV were studied over range of 200$800 \mathrm{~nm}$. Orange $\mathrm{G}$ reacts with PGZ-HCl and CRV to yield an orange colored chromophore exhibiting maximum absorption at $498 \mathrm{~nm}$ (Figures 16 and 17), and the ion pair formed can be extracted with methylene chloride.

\section{Different Variables Affecting the Reaction Were Studied}

(1) Effect of $p H$ on the Ion-Pair Formation. In order to establish the optimum $\mathrm{pH}$ value for each ion pair formed, various acids like hydrochloric, sulphuric, and acetic acids of different molarities were studied. The highest absorbance values were obtained using $0.5 \mathrm{M}$ sulphuric acid and $2 \mathrm{M}$ acetic acid for PGZ-HCl and CRV, respectively.

The optimum volume used for CRV was $0.2 \mathrm{~mL}$ of $2 \mathrm{M}$ acetic acid to give the highest absorbance values while $0.5 \mathrm{M}$ sulphuric acid was used as solvent for $\mathrm{PGZ}-\mathrm{HCl}$ and for acidification of the medium (Figure 18).

(2) Choice of Organic Solvents. The results using different extracting solvents (benzene, ethylacetate, methylene chloride and ethylene chloride) indicated that methylene chloride 


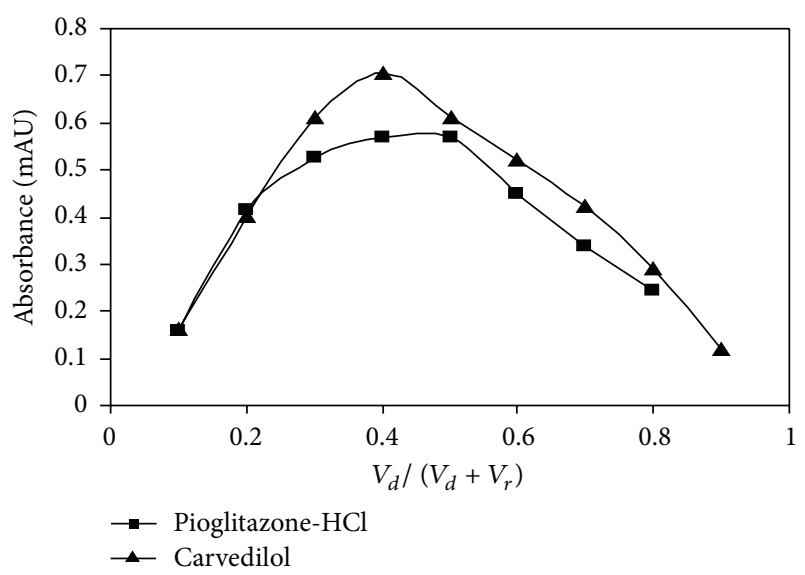

FIGURE 15: Continuous variation plot for PGZ-HCl $\left(1 \times 10^{-4} \mathrm{M}\right)$ and CRV $\left(1 \times 10^{-4} \mathrm{M}\right)$ with fast green FCF $\left(1 \times 10^{-4} \mathrm{M}\right)$.

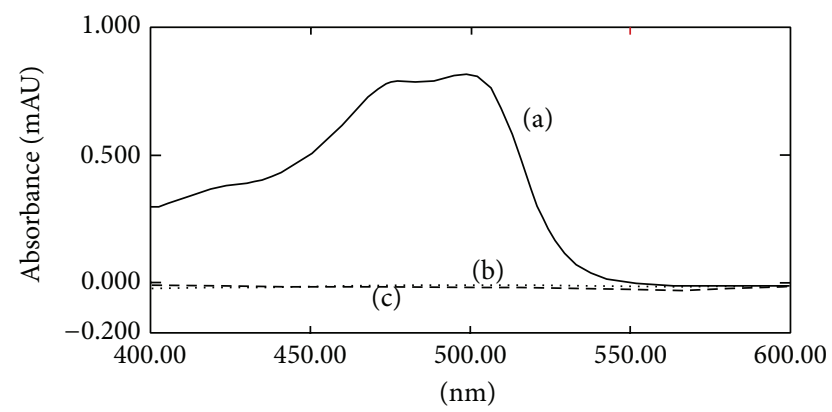

Figure 16: Absorption spectra of (a) the reaction of $60 \mu \mathrm{gmL}^{-1}$ PGZ- $\mathrm{HCl}$ with $0.5 \mathrm{~mL}$ orange $\mathrm{G}(0.4 \%$, w/v) against methylene chloride, (b) $0.5 \mathrm{~mL}$ orange $\mathrm{G}(0.4 \%$, w/v) against methylene chloride, and (c) $60 \mu \mathrm{gmL}^{-1}$ PGZ-HCl against methylene chloride.

is the most appropriate solvent for extraction and that can be attributed to its high extraction efficiency.

(3) Effect of Reagent Conc. and Volume as well as Additions Order. The effect of reagent concentration was also studied. Highest constant absorbance was obtained on using $0.5 \mathrm{~mL}$ of $(0.4 \% \mathrm{w} / \mathrm{v})$ and $(0.2 \% \mathrm{w} / \mathrm{v})$ orange $\mathrm{G}$ for PGZ-HCl and CRV, respectively (Figure 19). Moreover, the sequence of addition of the constituents of the complex was also studied. Addition of the drug followed by the dye and then the acid was recommended to obtain stable, high color intensity.

(4) Effect of Reaction Time and Number of Extraction Times. Reaction time required for complete color development of ion-pair complexes formed between the studied drugs and orange $G$ was studied. Maximum color intensity was attained immediately for both drugs. Complete extraction was attained by double extraction with $(2 \times 5 \mathrm{~mL})$ methylene chloride and then complete to $10 \mathrm{~mL}$ with the same solvent. The intensities of the color produced were found to be stable for about $1 \mathrm{hr}$ for both drugs (Figure 20).

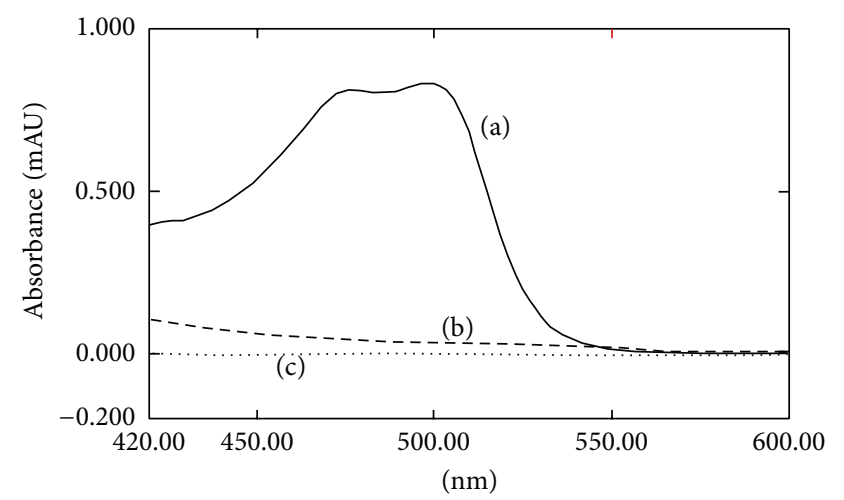

Figure 17: Absorption spectra of (a) the reaction of $40 \mu \mathrm{gmL}^{-1}$ CRV with $0.5 \mathrm{~mL}$ orange $\mathrm{G}(0.2 \%$, w/v), (b) $0.5 \mathrm{~mL}$ orange $\mathrm{G}(0.2 \%$, $\mathrm{w} / \mathrm{v}$ ) against methylene chloride, and (c) $40 \mu \mathrm{gmL}^{-1}$ CRV against methylene chloride.

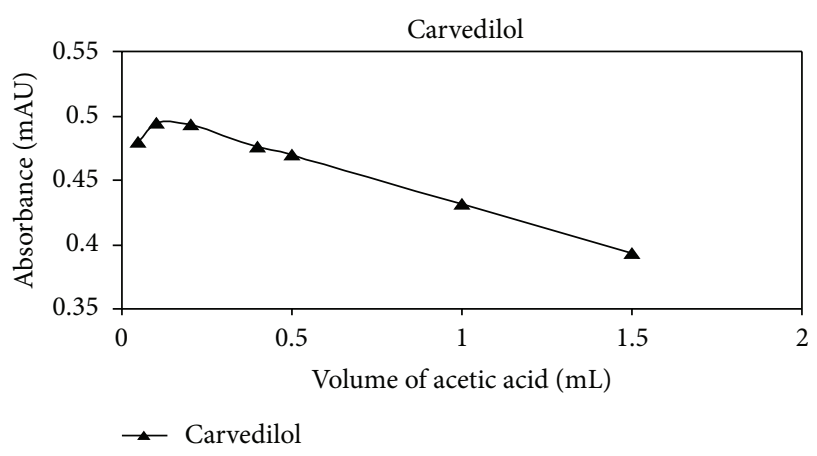

FIGURE 18: Effect of HAc volume on the ion-pair complex formation between $0.2 \% \mathrm{w} / \mathrm{v}$ orange $\mathrm{G}$ and $25 \mu \mathrm{gmL}^{-1} \mathrm{CRV}$.

(5) Composition of the Ion-Pair Complex. The composition of the ion-pair was studied by Job's method of continuous variation [44]. The obtained results showed that the composition of ion-pair complex was $(3: 2)$ (drug: reagent) for PGZ-HCl and $(1: 1)$ (drug: reagent) for CRV (Figure 21).

Method Validation. The method was validated according to the International Conference of Harmonization (ICH) [46].

\section{(1) Linearity and Concentration Ranges}

Fast Green FCF Method. Graph of the absorbance against concentrations proved to be linear in the range from 0.5 to $4 \mu \mathrm{gmL}^{-1}$ for PGZ-HCl and from 0.5 to $3 \mu \mathrm{gmL}^{-1}$ for CRV and determination coefficients $\left(R^{2}\right)$ were 0.9999 for both drugs (Table 5).

Orange GMethod. Graph of the absorbance against concentrations proved to be linear in the range from 10 to $70 \mu \mathrm{gmL}^{-1}$ for PGZ-HCl and from 5 to $45 \mu \mathrm{gmL}^{-1}$ for CRV 


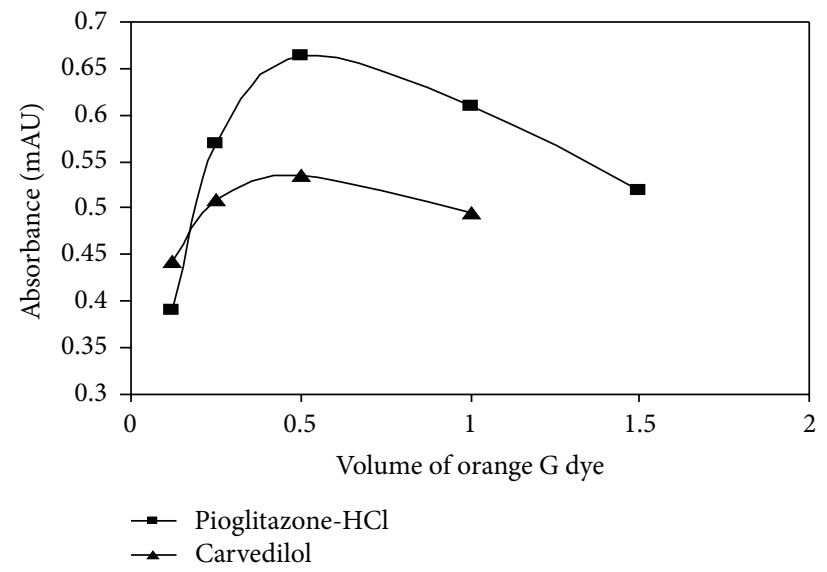

FIGURE 19: Effect of volume of $0.4 \% \mathrm{w} / \mathrm{v}$ and $0.2 \% \mathrm{w} / \mathrm{v}$ orange $\mathrm{G}$ dye on the ion-pair complex formation with $50 \mu \mathrm{gmL} \mathrm{PGZ}^{-1} \mathrm{PCl}$ and $25 \mu \mathrm{gmL}^{-1} \mathrm{CRV}$, respectively.

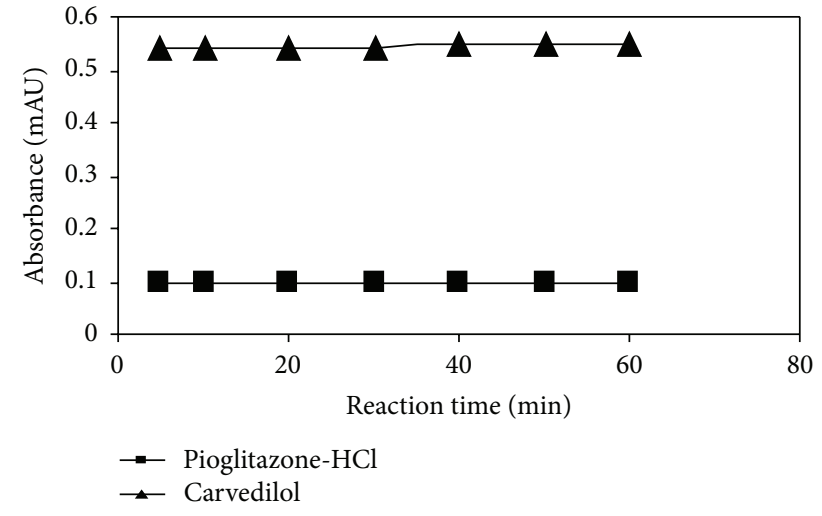

FIGURE 20: Stability of the ion pair formed between orange $G$ and both (i) $10 \mu \mathrm{gmL}^{-1} \mathrm{PGZ}-\mathrm{HCl}$ and (ii) $25 \mu \mathrm{gmL}^{-1} \mathrm{CRV}$.

and determination coefficients $\left(R^{2}\right)$ were 0.9999 for both drugs (Table 5).

\section{(2) Limits of Detection and Limits of Quantitation}

Fast Green FCF Method. Limit of detection (LOD) was found to be 0.13 and $0.078 \mu \mathrm{gmL}^{-1}$ for PGZ-HCl and CRV, respectively. Limit of quantitation (LOQ) was found to be $0.39 \mu \mathrm{gmL}^{-1}$ and $0.24 \mu \mathrm{gmL}^{-1}$ for PGZ-HCl and CRV, respectively.

Orange G Method. Limit of detection (LOD) was found to be 0.23 and $0.16 \mu \mathrm{gmL}^{-1}$ for $\mathrm{PGZ}-\mathrm{HCl}$ and $\mathrm{CRV}$, respectively. Limit of quantitation (LOQ) was found to be $0.7 \mu \mathrm{gmL}^{-1}$ and $0.49 \mu \mathrm{gmL}^{-1}$ for PGZ-HCl and CRV, respectively. Results are given in Table 6.

(3) Specificity of the Method. Results of the analysis were compared statistically to a reported method for $\mathrm{PGZ}-\mathrm{HCl}$ and CRV applying the Student's $t$-test and the variance ratio test (F-test). The results gave lower values than the theoretical ones indicating no significant difference between

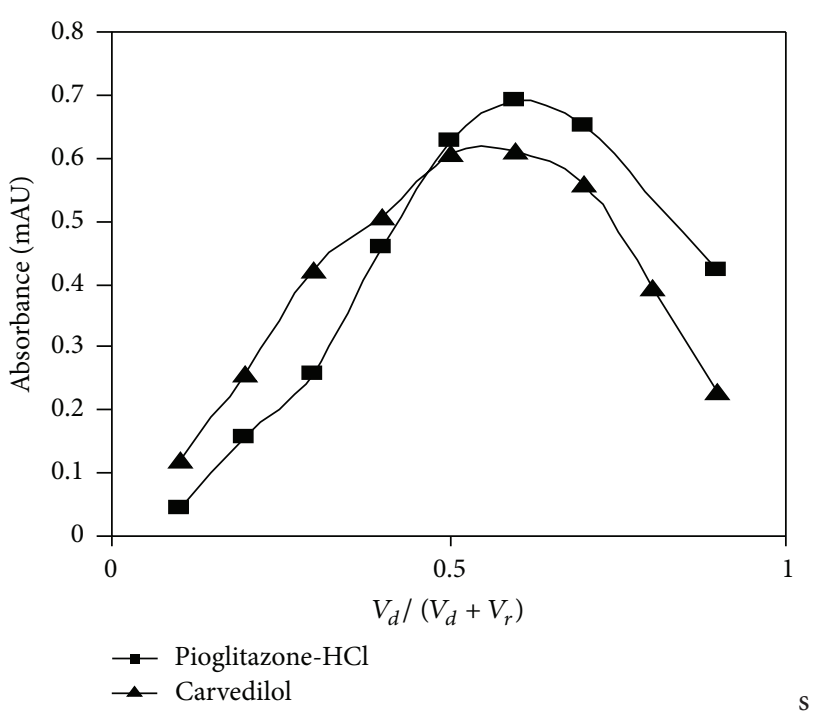

FIGURE 21: Continuous variation plot for PGZ-HCl $\left(2 \times 10^{-3} \mathrm{M}\right)$ with orange $\mathrm{G}\left(2 \times 10^{-3} \mathrm{M}\right)$ and $\mathrm{CRV}\left(7 \times 10^{-4} \mathrm{M}\right)$ with orange $\mathrm{G}(7 \times$ $\left.10^{-4} \mathrm{M}\right)$.

the performance of the proposed method and the reported methods (Table 7).

(4) Repeatability and Precision of the Method. Table 8 shows that there are high intra- and interday precision. Intraday precision was assessed by injection of the standard solution of the drug at three concentration levels six times during a day. The same was done for interday precision test except that the experiment was done and the drugs were analyzed every day for six days.

\section{Conclusions}

The two proposed methods for determination of PGZ and CRV are based on the formation of ion-pair associates 


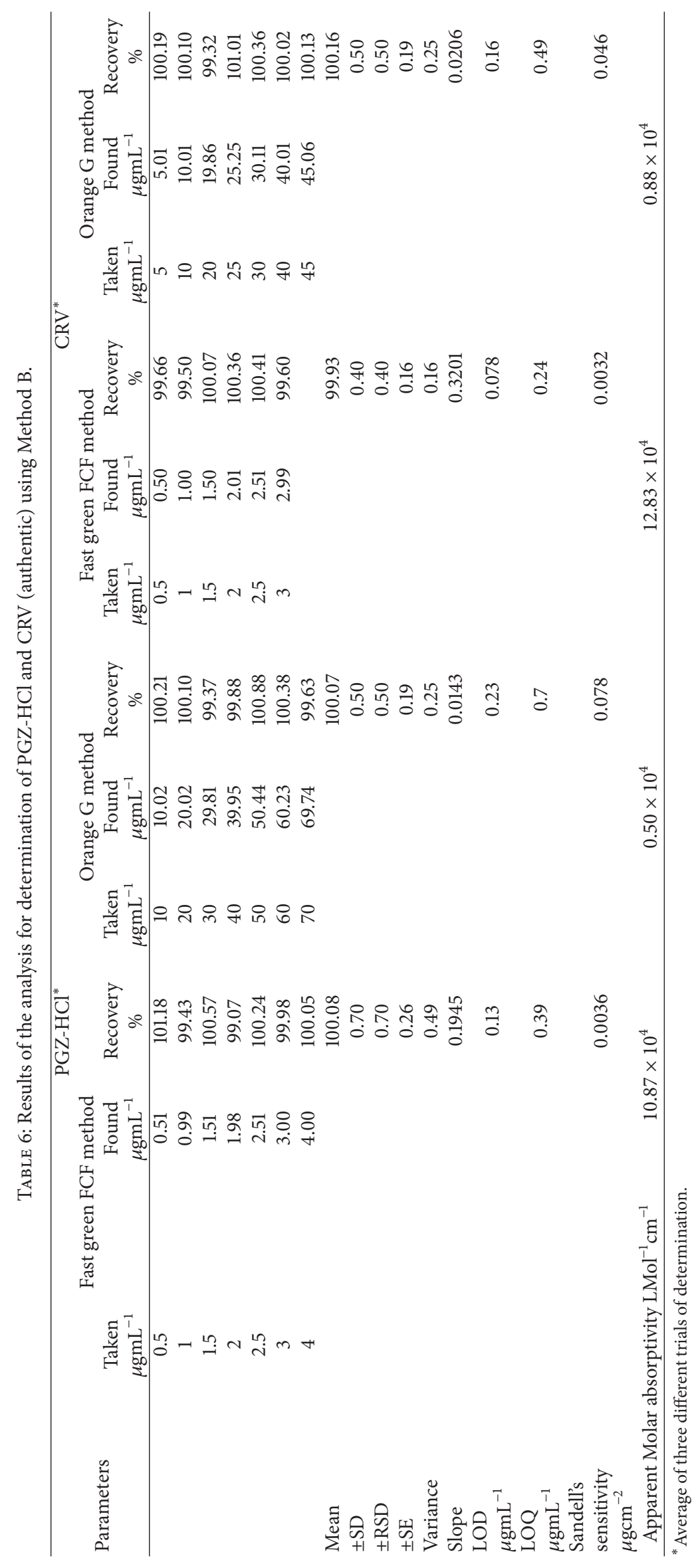


TABLE 7: Statistical analysis of results obtained by Method B applied on Diabetin tablets and Carvid tablets compared with reported methods.

\begin{tabular}{|c|c|c|c|c|c|c|}
\hline \multirow[b]{2}{*}{ Parameters } & \multicolumn{3}{|c|}{ Diabetin tablets } & \multicolumn{3}{|c|}{ Carvid tablets } \\
\hline & $\begin{array}{c}\text { Fast green } \\
\text { FCF }\end{array}$ & Orange G & $\begin{array}{c}\text { Reference } \\
\text { method } \\
{[12]}\end{array}$ & $\begin{array}{l}\text { Fast green } \\
\text { FCF }\end{array}$ & Orange G & $\begin{array}{l}\text { Reference } \\
\text { method [13] }\end{array}$ \\
\hline$N$ & 4 & 5 & 8 & 5 & 5 & 8 \\
\hline Mean recovery & 100.21 & 100.41 & 100.23 & 100.18 & 100.26 & 100.02 \\
\hline Variance & 0.51 & 0.50 & 0.85 & 0.38 & 0.28 & 0.64 \\
\hline$\pm \mathrm{SD}$ & 0.72 & 0.71 & 0.92 & 0.62 & 0.53 & 0.80 \\
\hline$\pm \mathrm{RSD}$ & 0.72 & 0.71 & 0.92 & 0.62 & 0.53 & 0.80 \\
\hline$\pm \mathrm{SE}$ & 0.36 & 0.32 & 0.33 & 0.28 & 0.24 & 0.28 \\
\hline Student's $t$-test & $\begin{array}{c}0.038 \\
(2.23)^{\mathrm{a}}\end{array}$ & $\begin{array}{c}0.41 \\
(2.20)^{\mathrm{a}}\end{array}$ & & $\begin{array}{c}1.33 \\
(2.20)^{\mathrm{a}}\end{array}$ & $\begin{array}{c}0.59 \\
(2.20)^{\mathrm{a}}\end{array}$ & \\
\hline$F$-test & $\begin{array}{c}1.67 \\
(4.35)^{\mathrm{b}} \\
\end{array}$ & $\begin{array}{c}1.70 \\
(4.12)^{\mathrm{b}} \\
\end{array}$ & & $\begin{array}{c}1.67 \\
(4.12)^{b} \\
\end{array}$ & $\begin{array}{c}2.27 \\
(4.12)^{\mathrm{b}} \\
\end{array}$ & \\
\hline
\end{tabular}

$\mathrm{a}$ and $\mathrm{b}$ are the theoretical student $t$-values and $F$-ratios at $P=0.05$.

TABLE 8: Evaluation of the interday and intraday precision and accuracy for PGZ-HCl and CRV obtained by Method B.

\begin{tabular}{|c|c|c|c|c|c|c|c|c|}
\hline \multirow[b]{2}{*}{ Drug } & \multirow[b]{2}{*}{ Method } & \multirow{2}{*}{$\begin{array}{l}\text { Taken } \\
\text { conc. } \\
\left(\mu \mathrm{gmL}^{-1}\right)\end{array}$} & \multicolumn{3}{|c|}{ Interday } & \multicolumn{3}{|c|}{ Intraday } \\
\hline & & & $\begin{array}{c}\text { Recovery } \\
(\%)^{\mathrm{a}}\end{array}$ & $\begin{array}{l}\text { Precision } \\
\left(^{(R S D \%)^{a}}\right.\end{array}$ & $\begin{array}{c}\text { Accuracy } \\
\text { (Er\%) }\end{array}$ & $\begin{array}{c}\text { Recovery } \\
(\%)^{\mathrm{a}}\end{array}$ & $\begin{array}{l}\text { Precision } \\
\left(^{(R S D \%}\right)^{a}\end{array}$ & $\begin{array}{c}\text { Accuracy } \\
\text { (Er\%) }\end{array}$ \\
\hline \multirow{6}{*}{ PGZ-HCl } & \multirow{3}{*}{$\begin{array}{l}\text { Fast } \\
\text { green }\end{array}$} & 1 & 98.94 & 1.80 & -1.06 & 99.24 & 1.03 & -0.76 \\
\hline & & 2 & 99.55 & 1.09 & -0.45 & 99.97 & 0.95 & -0.03 \\
\hline & & 3 & 100.13 & 0.78 & 0.13 & 98.65 & 1.17 & -1.35 \\
\hline & \multirow{3}{*}{ Orange $\mathrm{G}$} & 10 & 99.41 & 1.31 & -0.59 & 98.71 & 1.19 & -1.29 \\
\hline & & 30 & 101.45 & 0.98 & 1.45 & 99.89 & 1.17 & -0.11 \\
\hline & & 60 & 99.08 & 1.13 & -0.92 & 101.65 & 0.96 & 1.65 \\
\hline \multirow{6}{*}{ CRV } & \multirow{3}{*}{$\begin{array}{l}\text { Fast } \\
\text { green }\end{array}$} & 1 & 98.88 & 1.21 & -1.12 & 98.56 & 1.23 & -1.44 \\
\hline & & 2 & 101.76 & 0.86 & 1.76 & 99.87 & 1.38 & -0.13 \\
\hline & & 3 & 99.68 & 1.49 & -0.32 & 98.78 & 1.17 & -1.22 \\
\hline & \multirow{3}{*}{ Orange G } & 10 & 100.43 & 1.31 & 0.43 & 100.57 & 1.14 & 0.57 \\
\hline & & 25 & 98.13 & 0.87 & -1.87 & 101.67 & 1.26 & 1.67 \\
\hline & & 40 & 99.87 & 1.34 & -0.13 & 101.99 & 0.87 & 1.99 \\
\hline
\end{tabular}

RSD\%: percentage relative standard deviation.

Er\%: percentage relative error.

${ }^{\mathrm{a}}$ Mean of five trials of determination.

between the drugs and the inorganic complex, bismuth(III) tetraiodide (Method $\mathrm{A})$, and between the drugs and the organic acidic dyes, fast green and orange $\mathrm{G}$ (Method B). Both methods were found to be sensitive, accurate, and precise. When the results obtained by the proposed methods were compared with those of reference methods, there was no significant difference. The proposed methods were applied for determination of the analytes in drug dosage form with good accuracy and without interference.

\section{Conflict of Interests}

The authors declare that there is no conflict of interests regarding the publication of this paper.

\section{References}

[1] S. C. Sweetman, Martindale, the Complete Drug Reference, 36th edition, 2009.

[2] M. Chennaiah, T. Veeraiah, T. C. Singh, and G. Venkateshwarlu, "Extractive spectrophotometric methods for determination of PGZ using acidic triphenylmethane dyes," Asian Journal of Research in Chemistry, vol. 4, no. 6, pp. 971-975, 2011.

[3] Z. H. Qin, G. M. Shen, Y. S. Liu, and H. S. Luo, "Spectrophotometric method for determination of PGZ with eosin Y," Qinzonghui Fenxi Shiyanshi, vol. 27, no. 10, pp. 15-18, 2008.

[4] R. S. Mehta, D. M. Patel, K. K. Bhatt, and M. B. Shankar, "UV and visible spectrophotometric analysis of pioglitazone hydrochloride in bulk and tablets," Indian Journal of Pharmaceutical Sciences, vol. 67, no. 4, pp. 487-489, 2005. 
[5] K. Sujana, K. Abbulu, O. Bala Souri, B. Archana, M. Sindu, and G. Swathi Rani, "Difference spectrophotometric methods for pioglitazone hydrochloride and metform in hydrochloride," Journal of Pharmaceutical Sciences and Research, vol. 3, no. 4, pp. 1122-1126, 2011.

[6] S. Sharma and M. C. Sharma, "Determination of atorvastatin calcium and pioglitazone $\mathrm{HCl}$ in pharmaceutical formulations form by using atomic absorption spectrometry," Optoelectronics and Advanced Materials, Rapid Communications, vol. 4, no. 8, pp. 1196-1199, 2010.

[7] N. A. Al-Arfaj, E. A. Al-Abdulkareem, and F. A. Aly, "Flowinjection chemiluminometric determination of pioglitazone $\mathrm{HCl}$ by its sensitizing effect on the cerium-sulfite reaction," Analytical Sciences, vol. 25, no. 3, pp. 401-406, 2009.

[8] N. A. Al-Arfaj, E. A. Al-Abdulkareem, and F. A. Aly, "A validated adsorptive stripping voltammetric determination of antidiabetic agent pioglitazone $\mathrm{HCl}$ in tablets and biological fluids," International Journal of Biomedical Science, vol. 4, no. 4, pp. 310-318, 2008.

[9] A. A. Abdelmonem, G. H. Ragab, H. Hashem, and E. A. Bahgat, "High performance liquid chromatographic and spectrophotometric determinations of PGZ-HCl either alone or in combination with Metformin-HCl," Journal of Liquid Chromatography \& Related Technologies, vol. 35, pp. 2706-2723, 2012.

[10] A. Shirkhedkar and S. Surana, "Application of a stabilityindicating densitometric RP-TLC method for analysis of pioglitazone hydrochloride in the bulk material and in pharmaceutical formulations," Journal of Planar Chromatography: Modern TLC, vol. 22, no. 3, pp. 191-196, 2009.

[11] B. Siddartha and B. Sudheer, "Analytical method development and method validation for the estimation of PGZ in tablet dosage form by RP-HPLC," International Journal of Pharmacy and Pharmaceutical Sciences, vol. 5, no. 3, pp. 770-774, 2013.

[12] P. K. Basniwal, P. K. Srivastava, and D. Jain, "Spectrophotometric estimation of PGZ in tablet dosage form," Asian Journal of Pharmaceutical, vol. 2, pp. 225-227, 2008.

[13] N. Verma, A. K. Ghosh, and P. Chattopadhyay, "Simultaneous spectrophotometric determination of CRV in its dosage form," International Journal of Pharma Sciences and Research, vol. 1, no. 12, pp. 188-190, 2010.

[14] The British Pharmacopoeia, Volumes II and III, Her Majesty's Stationery Office, London, UK, 2009.

[15] S. G. Cardoso, C. V. S. Ieggli, and S. C. G. Pomblum, "Spectrophotometric determination of carvedilol in pharmaceutical formulations through charge-transfer and ion-pair complexation reactions," Pharmazie, vol. 62, no. 1, pp. 34-37, 2007.

[16] C. Theivarasu, S. Ghosh, and T. Indumathi, "UV spectrophotometric determination of carvedilol in pharmaceutical formulations," Asian Journal of Pharmaceutical and Clinical Research, vol. 3, no. 4, pp. 64-68, 2010.

[17] Y. N. Rani, B. V. Ravikumar, and S. Mohanty, "Development and validation of new analytical methods for the estimation of carvedilol in bulk and pharmaceutical dosage forms," Asian Journal of Pharmaceutical and Clinical Research, vol. 6, no. 2, pp. 138-140, 2013.

[18] S. D. Manohar, D. A. Sridhar, and S. C. Mallikarjuna, "Development of UV spectrophotometric method for estimation of carvedilol in bulk and pharmaceutical formulations," Asian Journal of Research in Chemistry, vol. 6, no. 10, pp. 956-959, 2013.

[19] I. Leonenko, D. Aleksandrova, and A. Yegorova, "Determination of carvedilol by its quenching effect on the luminescence of terbium complex in dosage form," Acta Poloniae Pharmaceutica: Drug Research, vol. 68, no. 3, pp. 325-330, 2011.

[20] A. Önal, "Spectrophotometric and spectrofluorimetric determination of some drugs containing secondary amino group in bulk drug and dosage forms via derivatization with 7-chloro-4nitrobenzofurazon," Química Nova, vol. 34, no. 4, pp. 677-682, 2011.

[21] C. V. S. Ieggli, S. G. Cardoso, and L. P. Belle, "Validation of UV spectrophotometric and nonaqueous titration methods for the determination of carvedilol in pharmaceutical formulations," Journal of AOAC International, vol. 88, no. 5, pp. 1299-1303, 2005.

[22] R. S. Haggag, R. A. Shaalan, and T. S. Belal, "Validated HPLC determination of the two fixed dose combinations (chlordiazepoxide hydrochloride and mebeverine hydrochloride; carvedilol and hydrochlorothiazide) in their tablets," Journal of AOAC International, vol. 93, no. 4, pp. 1192-1200, 2010.

[23] P. Sripalakit, S. Kaewnok, and S. Tubtonglang, "Development of carvedilol assay in tablet dosage form using HPLC with fluorescence detection," Maejo International Journal of Science and Technology, vol. 4, no. 1, pp. 8-19, 2010.

[24] J. Stojanovi, S. Vladimirov, V. Marinkovi, D. Velikovi, and P. Sibinovi, "Monitoring of the photochemical stability of CRV and its degradation products by the RP-HPLC method," Journal of the Serbian Chemical Society, vol. 72, pp. 37-44, 2007.

[25] M. Sylwia, A. Weronika, and B. Irena, "Simultaneous chiral separation and determination of CRV and 5/-hydroxyphenyl CRV enantiomers from human urine by high performance liquid chromatography coupled with fluorescent detection," Central European Journal of Chemistry, vol. 11, no. 12, pp. 20762087, 2013.

[26] T. S. Belal, F. A. El Yazbi, R. A. Shaalan, and S. M. Elonsy, "Validated stability-indicating HPLC-DAD determination of the antihypertensive binary mixture of carvedilol and hydrochlorothiazide in tablet dosage forms," Chromatographia, vol. 76, no. 23-24, pp. 1707-1720, 2013.

[27] D. P. Patel, P. Sharma, M. Sanyal, P. Singhal, and P. S. Shrivastav, "UPLC-MS/MS assay for the simultaneous quantification of carvedilol and its active metabolite 4'-hydroxyphenyl carvedilol in human plasma to support a bioequivalence study in healthy volunteers," Biomedical Chromatography, vol. 27, no. 8, pp. 974986, 2013.

[28] F. M. Abdel-Gawad, "Ion-pair formation of Bi(III)-iodide with some nitrogenous drugs and its application to pharmaceutical preparations," Journal of Pharmaceutical and Biomedical Analysis, vol. 16, no. 5, pp. 793-799, 1998.

[29] L. M. Abdellaziz and M. M. Hosny, "Development and validation of spectrophotometric, atomic absorption and kinetic methods for determination of moxifloxacin hydrochloride," Analytical Chemistry Insights, vol. 6, no. 1, pp. 67-78, 2011.

[30] A. M. El-Brashy, M. E.-S. Metwally, and F. A. El-Sepai, "Spectrophotometric and atomic absorption spectroscopic determination of some fluoroquinolone antibacterials by ion-pair complex formation with bismuth (III) tetraiodide," Journal of the Chinese Chemical Society, vol. 52, no. 2, pp. 253-262, 2005.

[31] M. Ayad, H. Abdellatef, M. Hosny, and N. Kabil, "Conductometric determination of certain pharmacological drugs using silver and bismuth," International Research Journal of Pharmaceutical and Applied Sciences, vol. 3, no. 4, pp. 140-148, 2013.

[32] C. S. P. Sastry, M. Aruna, M. Narayana Reddy, and D. G. Sankar, "Extractive spectrophotometric determination of some 
anthelmintics using fast green FCF or orange-II," Indian Journal of Pharmaceutical Sciences, vol. 50, no. 2, pp. 140-142, 1988.

[33] K. Sreedhar, C. S. P. Sastry, M. Narayana Reddy, and D. G. Sankar, "Spectrophotometric determination of mebeverine hydrochloride," Mikrochimica Acta, vol. 126, no. 1-2, pp. 131-135, 1997.

[34] M. Kishore, K. Surendrababu, C. S. R. G. Kalyani, and M. Janardhan, "Spectrophotometric determination of ceftiofur in pharmaceutical formulations by FGFCF, SFNO and MB," Journal of Pharmaceutical Sciences and Research, vol. 2, no. 9, pp. 534-538, 2010.

[35] L. Qiu-hua, "Kinetic spectrophotometric determination of trace ruthenium with fast green FCF," Chinese Journal of Analysis Laboratory, vol. 26, pp. 60-62, 2007.

[36] J. Zhiliang and Q. Qin Chen-zhen, "A new application of fast green in catalytic analysis-catalytic determination of ultratrace ruthenium with oscillopolarographic detection," Electroanalysis, vol. 5, pp. 535-537, 1993.

[37] S. Pillai and I. Singhvi, "Application of orange G dye for quantitation of citalopram hydrobromide, donepezil hydrochloride and rabeprazole sodium from tablet formulation," Indian Journal of Pharmaceutical Sciences, vol. 68, no. 5, pp. 682-684, 2006.

[38] A. Bhandage, A. Bhosale, A. Kasture, and V. P. Godse, "Extractive spectrophotometric determination of omeprazole in pharmaceutical preparations," Tropical Journal of Pharmaceutical Research, vol. 8, no. 5, pp. 449-454, 2009.

[39] B. Rajitha, S. Prashanthi, K. Ramsubha Reddy, and G. Tulja Rani, "Extractive spectrophotometric determination of tramadol hydrochloride in pure and pharmaceutical dosage forms," International Journal of PharmTech Research, vol. 3, no. 1, pp. 114-117, 2011.

[40] R. Tulja Rani, D. Gowri Sankar, P. Kadgapathi, R. Suthakaran, and B. Satyanarayana, "Visible spectrophotometric methods for the determination of drotaverine hydrochloride in bulk and in pharmaceutical formulations," International Journal of PharmTech Research, vol. 2, no. 3, pp. 1787-1791, 2010.

[41] H. M. Saleh, M. M. EL-Henawee, G. H. Ragab, and S. S. Abd EL-Hay, "Extractive spectrophotometric determination of some antihistaminic and skeletal muscle relaxant drugs through ionpair formation with xylene cyanol and orange G," Bulletin of Faculty of Pharmacy Cairo University, vol. 45, no. 3, pp. 373-390, 2007.

[42] G. Jie, Y. Ming-Hui, Y. Zhi-Yi, L. Zu-Bi, and C. Qiu-E, "Kinetic spectrophotometric determination of trace ruthenium with orange G," Chinese Journal of Analysis Laboratory, vol. 2, pp. 3840, 2005.

[43] S. Motomizu, M. Oshima, and Y. Hosoi, "Spectrophotometric determination of cationic and anionic surfactants with anionic dyes in the presence of nonionic surfactants, part I: a general aspect," Mikrochimica Acta, vol. 106, no. 1-2, pp. 57-66, 1992.

[44] J. Mendham, R. C. Denney, J. D. Barnes, and M. Thomas, Vogel's Textbook of Quantitative Chemical Analysis, Pearson Education, Essex, UK, 2000.

[45] W. C. Vosburg and G. R. Cooper, "Job method of non equimolar solution," Journal of the American Chemical Society, vol. 63, pp. 437-442, 1941.

[46] "Guidance for Industry: Q2B of Analytical Procedures, Methodololgy: International Conference of Harmonization (ICH)," 1996. 

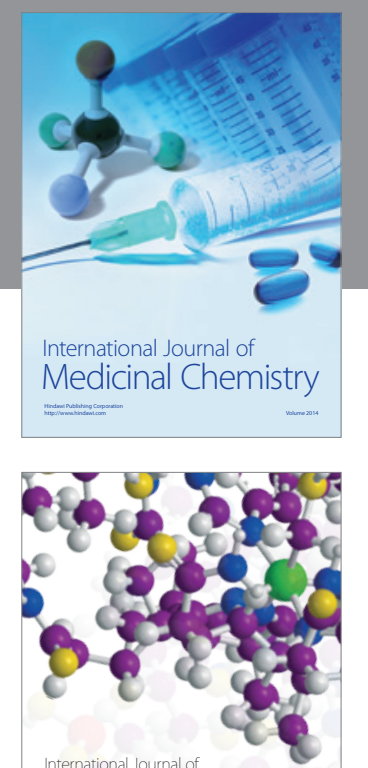

\section{Carbohydrate} Chemistry

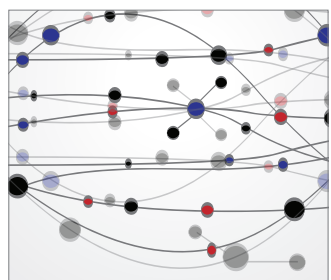

The Scientific World Journal
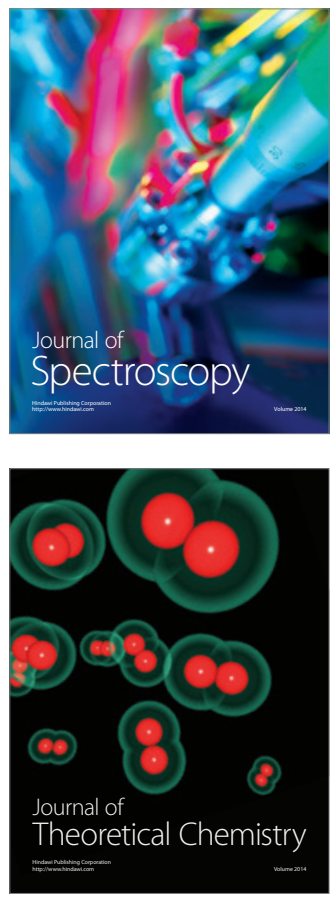
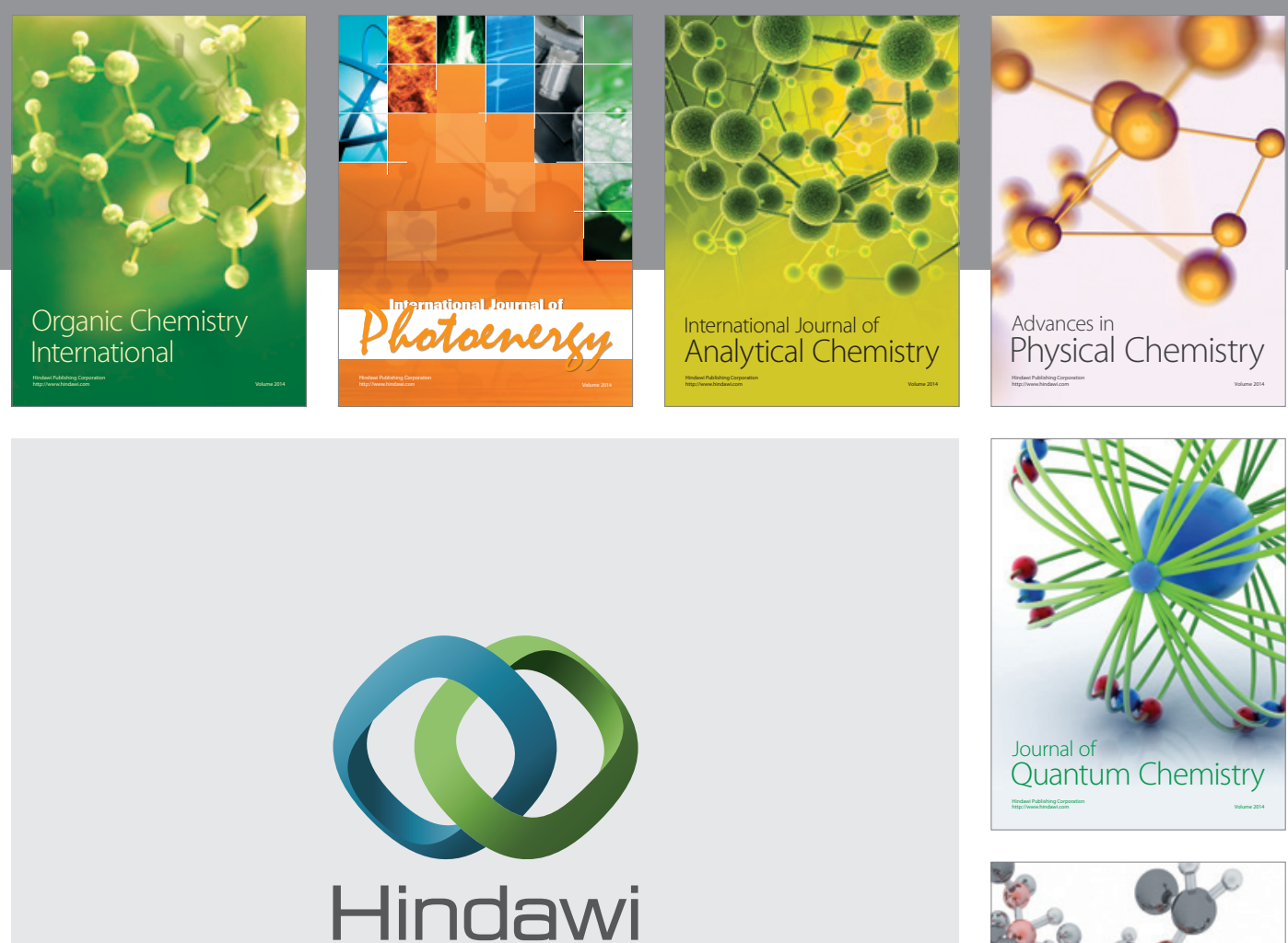

Submit your manuscripts at

http://www.hindawi.com

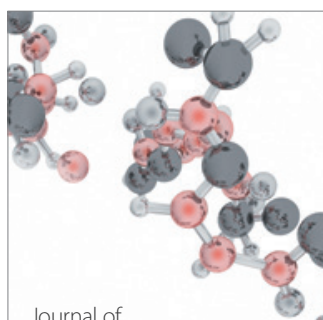

Analytical Methods

in Chemistry

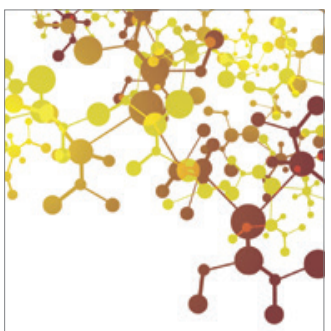

Journal of

Applied Chemistry

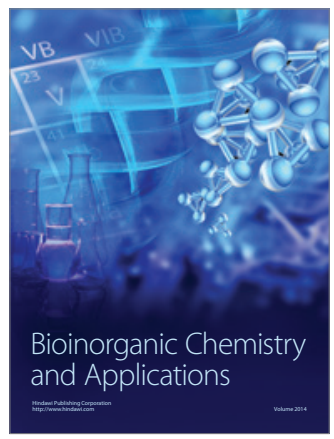

Inorganic Chemistry
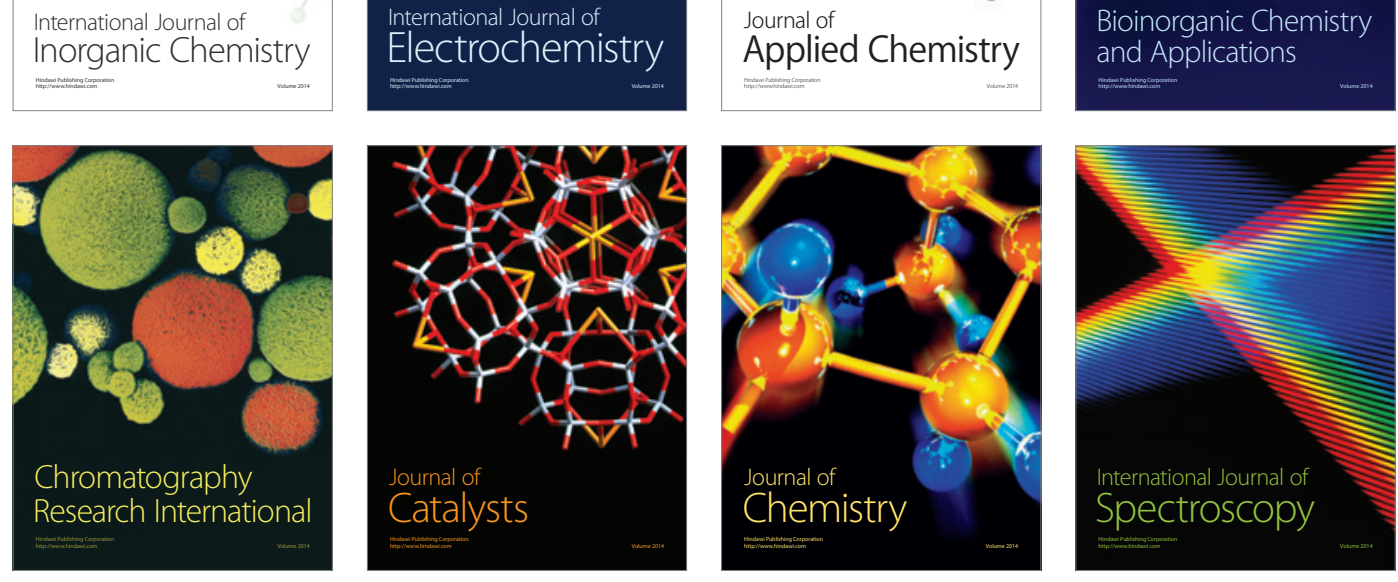